\title{
PDGF-BB regulates the pulmonary vascular tone: impact of prostaglandins, calcium, MAPK- and PI3K/AKT/mTOR signalling and actin polymerisation in pulmonary veins of guinea pigs
}

Annette D. Rieg ${ }^{1 *}$ (D) Said Suleiman², Carolin Anker², Eva Verjans², Rolf Rossaint', Stefan Uhlig ${ }^{2}$ and Christian Martin ${ }^{2}$

\begin{abstract}
Background: Platelet-derived growth factor (PDGF)-BB and its receptor PDGFR are highly expressed in pulmonary hypertension (PH) and mediate proliferation. Recently, we showed that PDGF-BB contracts pulmonary veins (PVs) and that this contraction is prevented by inhibition of PDGFR- $\beta$ (imatinib/SU6668). Here, we studied PDGF-BBinduced contraction and downstream-signalling in isolated perfused lungs (IPL) and precision-cut lung slices (PCLS) of guinea pigs (GPs).

Methods: In IPLs, PDGF-BB was perfused after or without pre-treatment with imatinib (perfused/nebulised), the effects on the pulmonary arterial pressure $\left(P_{P A}\right)$, the left atrial pressure $\left(P_{L A}\right)$ and the capillary pressure $\left(P_{c a p}\right)$ were studied and the precapillary $\left(R_{\text {pre }}\right)$ and postcapillary resistance $\left(R_{\text {post }}\right)$ were calculated. Perfusate samples were analysed (ELISA) to detect the PDGF-BB-induced release of prostaglandin metabolites (TXA $/ \mathrm{PGI}_{2}$ ). In PCLS, the contractile effect of PDGF-BB was evaluated in pulmonary arteries (PAs) and PVs. In PVs, PDGF-BB-induced contraction was studied after inhibition of PDGFR- $\alpha / \beta$, L-Type $\mathrm{Ca}^{2+}$-channels, ROCK/PKC, prostaglandin receptors, MAP2K, p38-MAPK, PI3K-a/Y, AKT/PKB, actin polymerisation, adenyl cyclase and NO. Changes of the vascular tone were measured by videomicroscopy. In PVs, intracellular cAMP was measured by ELISA.
\end{abstract}

Results: In IPLs, PDGF-BB increased $\mathrm{P}_{\mathrm{PA}_{\mathrm{A}}} \mathrm{P}_{\mathrm{cap}}$ and $\mathrm{R}_{\text {post. }}$ In contrast, PDGF-BB had no effect if lungs were pre-treated with imatinib (perfused/nebulised). In PCLS, PDGF-BB significantly contracted PVs/PAs which was blocked by the PDGFR- $\beta$ antagonist SU6668. In PVs, inhibition of actin polymerisation and inhibition of L-Type $\mathrm{Ca}^{2+}$-channels reduced PDGF-BB-induced contraction, whereas inhibition of ROCK/PKC had no effect. Blocking of EP $1 / 3^{-}$and TPreceptors or inhibition of MAP2K-, p38-MAPK-, PI3K-a/Y- and AKT/PKB-signalling prevented PDGF-BB-induced contraction, whereas inhibition of $\mathrm{EP}_{4}$ only slightly reduced it. Accordingly, PDGF-BB increased TXA $\mathrm{A}_{2}$ in the perfusate, whereas $\mathrm{PG}_{2}$ was increased in all groups after $120 \mathrm{~min}$ and inhibition of IP-receptors did not enhance PDGF-BB-induced contraction. Moreover, PDGF-BB increased CAMP in PVs and inhibition of adenyl cyclase enhanced PDGF-BB-induced contraction, whereas inhibition of NO-formation only slightly increased it.

Conclusions: PDGF-BB/PDGFR regulates the pulmonary vascular tone by the generation of prostaglandins, the increase of calcium, the activation of MAPK- or PI3K/AKT/mTOR signalling and actin remodelling. More insights in PDGF-BB downstream-signalling may contribute to develop new therapeutics for $\mathrm{PH}$.

\footnotetext{
*Correspondence: arieg@ukaachen.de

'Department of Anaesthesiology, Medical Faculty RWTH-Aachen, Aachen,

Germany

Full list of author information is available at the end of the article
}

(c) The Author(s). 2018 Open Access This article is distributed under the terms of the Creative Commons Attribution 4.0 International License (http://creativecommons.org/licenses/by/4.0/), which permits unrestricted use, distribution, and reproduction in any medium, provided you give appropriate credit to the original author(s) and the source, provide a link to the Creative Commons license, and indicate if changes were made. The Creative Commons Public Domain Dedication waiver (http://creativecommons.org/publicdomain/zero/1.0/) applies to the data made available in this article, unless otherwise stated. 


\section{Background}

Regulation of platelet-derived growth factor (PDGF)-BB and its receptor PDGFR- $\beta$ are strongly involved in the pathogenesis of pulmonary hypertension $(\mathrm{PH})[1,2]$, as they highly act proliferative on pulmonary vessel [3]. This instance provides for the fact that PDGFR-inhibition by tyrosine kinase inhibitors (TKIs), e.g. imatinib, resembles a new intriguing approach to treat $\mathrm{PH}$, as it counteracts the vascular remodelling [4]. Recent research also revealed considerable pulmonary vasorelaxant effects of TKIs, e.g. imatinib relaxes the pulmonary arterial bed of healthy and pulmonary hypertensive rats $[5,6]$. Within this context, the relaxant effects of TKIs appear to be not limited to the pulmonary arterial bed, as imatinib, just as the PDGFR- $\beta$-inhibitors SU6668 or DMPQ also relax pulmonary veins (PVs) [7]. With regard to imatinib, it even exerts pulmonary venous relaxation if it is inhaled [7]. The dual action of imatinib on pulmonary vascular remodelling and vessel tone $[2,5-7]$ is still more remarkable, as PDGF-BB also contracts PVs [7]. Consecutively, aside the involvement in vascular remodelling $[2,3]$, PDGF-BB and PDGFR appear to regulate the tone of pulmonary vessels. In this regard, previous studies in systemic vessel revealed conflictive results of PDGF, e.g. contraction of the basilar artery [8] or aorta $[9,10]$, but relaxation of the mesenteric artery $[11$, 12].

PDGFR consists of two subunits, either $\alpha \alpha, \alpha \beta$ or $\beta \beta$ and all of them are assigned to various functions, e.g. PDGFR- $\alpha$ is involved in organogenesis (lungs, skin, gonads or central nervous system), whereas PDGFR- $\beta$ is responsible for the formation of vessel [3] and for proliferation in pulmonary vascular remodelling [1]. The various PDGFR subunits are activated by different ligands, e.g. in vivo PDGFR- $\alpha$ is activated by PDGF-AA or PDGF-CC, whereas PDGFR- $\beta$ is activated by PDGF-BB [3]. In contrast, more possibilities are conceivable in vitro, e.g. the activation of PDGFR- $\alpha \beta$ by PDGF-BB [3].

We designed this study to evaluate the contractile effects of PDGF-BB on the pulmonary arterial and venous bed in isolated perfused lungs (IPL) of guinea pigs (GPs) [7, 13, 14]. Further, we analysed the PDGF-BB-induced release of the prostaglandins $\mathrm{TXA}_{2}$ and $\mathrm{PGI}_{2}$ in supernatants of IPL-perfusate samples. Next, we compared the contractile effect of PDGF-BB in pulmonary arteries (PAs) or PVs after or without inhibtion of PDGFR- $\alpha$ (ponatinib) or PDGFR- $\beta$ (SU6668) in GPs' precision-cut lung slices (PCLS) [13, 15, 16]. Further, we studied the mechanisms beyond PDGF-BB-induced contraction in PVs. In this context, we examined the involvement of L-Type $\mathrm{Ca}^{2+}$-channels, $\mathrm{Ca}^{2}$ ${ }^{+}$-sensitisation (ROCK/PKC), prostaglandin receptors and cellular pathways such as p38-MAPK, MAP2K, PI3K- $\alpha / \gamma$, or $\mathrm{AKT} / \mathrm{PKB}$. Beyond that, we evaluated the impact of signalling cascades generally attributed to vasorelaxation; e.g. $\mathrm{PGI}_{2}$, cAMP or NO. Within the framework of the above mentioned signalling cascades, smooth muscle cell (SMC) contraction depends on myosin light chain (MLC) phosphorylation, regulated either by $\mathrm{Ca}^{2+}$-sensitisation or by the increase of intracellular calcium [17-25]. Aside MLC phosphorylation, SMC contraction depends on actin polymerisation and cytoskeletal remodeling [26, 27] which we inhibited by cytochalasin D and latrunculin A.

PCLS resembles an ex vivo model which allows to study the tone of PAs, PVs and airways concurrently within their tissue organisation excluding the exposure to in vivo factors such as shear stress, vascular filling pressure or thromboembolism [13, 15, 16, 28]. As a major advantage, PCLS allow to compare how pulmonary vessel or airways react to several stimulants within the different species [13, 28-30].

With regard to $\mathrm{PH}$, there are multiple open questions concerning the role of PDGF-BB and PDGFR. We adressed the following points: 1) Does PDGF-BB contract in addition to PVs also PAs and is this contraction related to PDGFR- $\beta$ ? 2) How does PDGF-BB alter $\mathrm{P}_{\mathrm{PA}}, \mathrm{P}_{\text {cap }}, \mathrm{R}_{\text {pre }}$ and $\mathrm{R}_{\text {post }}$ in IPLs? 3) How does PDGF-BB affect the pulmonary vascular tone, if lungs are pre-treated with the TKI imatinib (perfused/inhaled)? 4) What are the mechanisms beyond PDGF-BB-induced contraction?

\section{Methods}

\section{Lung tissue from GPs'}

Female Dunkin Hartley GPs $(350 \pm 50 \mathrm{~g})$ were delivered from Charles River (Sulzfeld, Germany). All animal experiments were approved by the Landesamt für Natur, Umwelt und Verbraucherschutz Nordrhein-Westfalen (ID: 84-02.04.2013A146, 8.87-51.05.20.10.245 and 50066A4) and strictly performed according to the rules of the Directive 2010/63/EU of the European Parliament.

\section{Isolated perfused lungs of the GP}

GPs' lungs were prepared as described [7, 13, 14]. In brief, intraperitoneal anaesthesia was performed (pentobarbital: $95 \mathrm{mg} \mathrm{kg}{ }^{-1}$ ) and verified by missing reflexes. The animal was exsanguinated, the trachea cannulated and the lung ventilated with positive pressure (70 breaths/min). The apex of the left ventricle was cut and cannulas were placed in the PA (perfusion inflow) and in the left atrium (perfusion outflow). The lung was perfused at constant flow (20 $\mathrm{mL} / \mathrm{min}$ ) with Krebs-Henseleit buffer, containing 2\% bovine serum albumin, $0.1 \%$ glucose, $0.3 \%$ HEPES and $50 \mathrm{nM}$ salbutamol to prevent bronchoconstriction [31]. The temperature of the perfusate was maintained at $37{ }^{\circ} \mathrm{C}$ with a water bath and the $\mathrm{pH}$ was adjusted between 7.35 and 7.45 by gassing with $\mathrm{CO}_{2}$. Heart and lungs were withdrawn and transferred into a negative-pressure chamber, the so-called artificial thorax chamber. Next, ventilation was switched from positive pressure to negative pressure. To prevent the formation of lung oedema during constant 


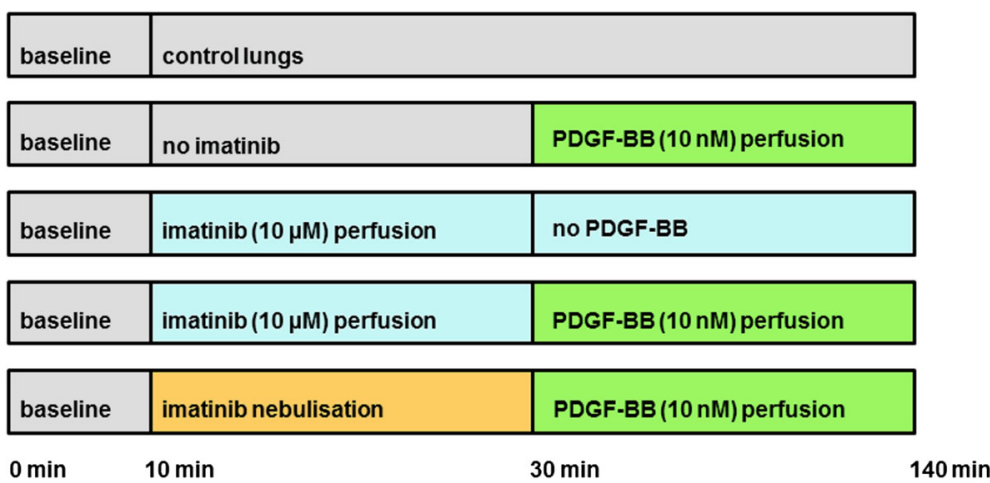

Fig. 1 Overview of the timeline. This overview illustrates the different groups and the timeline of all experiments using the IPL

flow perfusion and negative pressure ventilation, a pressure balancing chamber was established in the perfusion outflow which was connected by tubing to the artificial thorax chamber. To prevent atelectasis of the lung, every 5 min a deep breath was applied. Tidal volume (TV), dynamic compliance (Cdyn), resistance (Res), pulmonal arterial pressure $\left(\mathrm{P}_{\mathrm{PA}}\right)$, left atrial pressure $\left(\mathrm{P}_{\mathrm{LA}}\right)$ and the flow were continuously monitored. Further, the capillary pressure $\left(\mathrm{P}_{\text {cap }}\right)$ was measured every $10 \mathrm{~min}$ by the double occlusion method [14] and the precapillary $\left(\mathrm{R}_{\text {pre }}\right)$ and postcapillary resistance $\left(R_{\text {post }}\right)$ were calculated by the following equations: $R_{\text {pre }}=$ $\frac{P P A-P c a p}{\text { flow }}$ and $\mathrm{R}_{\text {post }}=\frac{P c a p-P L A}{\text { flow }}$.

As soon as respiratory and haemodynamic parameters remained stable over $10 \mathrm{~min}$ (baseline), imatinib $(10 \mu \mathrm{M})$ was perfused at time point $10 \mathrm{~min}$. At a buffer volume of $200 \mathrm{~mL}$, a concentration of $10 \mu \mathrm{M}$ imatinib corresponds to a total dose of $1.18 \mathrm{mg}$ imatinib or to $3.5 \mathrm{mg} / \mathrm{kg}$ body weight imatinib, respectively. Control lungs remained untreated. Next, PDGF-BB $(10 \mathrm{nM})$ was added to the recirculating perfusion buffer (total volume $200 \mathrm{~mL}$ ) at time point $30 \mathrm{~min}$ and perfused in untreated lungs and imatinib-pre-treated lungs. Beyond that, imatinib mesylate was nebulised in some lungs prior to the perfusion of PDGF-BB. Therefore, $29.38 \mathrm{mg}$ imatinib mesylate were solved in $3 \mathrm{ml}$ aqua to obtain a solution of $16.6 \mathrm{mM}$ and nebulised over a period of $130 \mathrm{~min}$. Assuming a lung flow of $0,21 \mathrm{~L} / \mathrm{min}$ (70 breaths à $3 \mathrm{~mL}$ ) and a pressure of $1.5 \mathrm{bar}$, the total amount of inhaled imatinib corresponds to less than $4 \%$ of the nebulised amount of imatinib [32], namely $1.18 \mathrm{mg}$, corresponding to $3.5 \mathrm{mg} / \mathrm{kg}$ body weight imatinib, respectively. To measure $\mathrm{PGI}_{2}$ and $\mathrm{TXA}_{2}$, IPL-perfusate samples were obtained at time point 0,30 (before the application of PDGF-BB) and $120 \mathrm{~min}$. The different groups and the timeline of the experiments are illustrated in Fig. 1.

\section{Precision-cut lung slices (PCLS) from GPs}

In GPs, intraperitoneal anaesthesia was performed with $95 \mathrm{mg} \mathrm{kg}^{-1}$ pentobarbital (Narcoren; Garbsen, Germany) and verified by missing reflexes. The GP was bled, the trachea cannulated and the diaphragm opened. Thereafter, PCLS were prepared as described before [13, 16, 30]. Whole lungs were filled via the trachea with $1.5 \%$ low-melting agarose and cooled on ice to harden the lungs. Afterwards, tissue cores (diameter $11 \mathrm{~mm}$ ) were prepared and cut into $300 \mu \mathrm{m}$ thick slices with a Krumdieck tissue slicer (Alabama Research \& Development, Munford, AL, USA). PCLS were incubated at $37^{\circ} \mathrm{C}$ and repeated medium changes were performed to wash out the agarose.

\section{Identification of the vessels, histology}

Pulmonary vessels from GPs were identified by their anatomical landmarks; e.g. PAs accompany the airways and PVs lie aside $[13,16]$.

\section{Pharmacological interventions, measurements and videomicroscopy}

To evaluate the contractile effect of PDGF-BB in PAs/ PVs from GPs, PCLS were exposed for $60 \mathrm{~min}$ to $100 \mathrm{nM}$ PDGF-BB (Figs. 3, 4 and 5, Figs 7, 8 and 9). If a signalling pathway was evaluated (Figs. 3,4 and 5, Figs 7, 8 and 9), PCLS were additionally pre-treated for $1 \mathrm{~h}$ with one of the following inhibitors at concentrations about 10-100 fold above the $\mathrm{IC}_{50}$ value of the target: PDGFR- $\alpha$ : $100 \mathrm{nM}$ ponatinib $\left(\mathrm{IC}_{50}: 1.1 \mathrm{nM}\right)$ [33-35]; PDGFR- $\beta$ : $5 \mu \mathrm{M}$ SU6668 $\left(\mathrm{IC}_{50}: 0.008-0.1 \mu \mathrm{M}\right)$ [36-38]; PDGFR- $\alpha / \beta$ : $100 \mu \mathrm{M}$ imatinib $\left(\mathrm{IC}_{50}: 0.6-1.8 \mu \mathrm{M}\right)$ [39]; L-Type $\mathrm{Ca}^{2+}$-channels: $100 \mathrm{nM}$ amlodipine $\left(\mathrm{IC}_{50}\right.$ : $1.9 \mathrm{nM}$ ) [40]; Rho-Kinase: $10 \mu \mathrm{M}$ fasudile ( $\mathrm{IC}_{50}: 1.4 \mu \mathrm{M}$ ) [41]; protein kinase $\mathrm{C}(\mathrm{PKC}): 5 \mu \mathrm{M}$ calphostin $\mathrm{C}\left(\mathrm{IC}_{50}\right.$ : $50 \mathrm{nM}$ ) [42]; cyclooxygenase 1/2: $3 \mu \mathrm{M}$ indomethacin $\left(\mathrm{IC}_{50}: 13-26 \mathrm{nM}\right)[43,44] ; \mathrm{EP}_{1}: 1 \mu \mathrm{M} \operatorname{SC51322}\left(\mathrm{IC}_{50}\right.$ : $13.8 \mathrm{nM}$ ) [45]; EP $: 1 \mu \mathrm{M}$ PF04418948 ( $\mathrm{IC}_{50}: 2.7 \mathrm{nM}$ ) [46, 47]; EP ${ }_{3}: 1 \mu \mathrm{M}$ L798106 (IC 50 : $\left.10 \mathrm{nM}\right)[48,49]$; $\mathrm{EP}_{4}$ : $1 \mu \mathrm{M}$ L161982 (IC $\mathrm{I}_{50}: 3.2 \mathrm{nM}$ ) [48]; TP: $10 \mu \mathrm{M}$ SQ29548 $\left(\mathrm{IC}_{50} 10 \mathrm{nM}\right)$ [48]; IP: $1 \mu \mathrm{M}$ RO-1138452 (IC 5 : 5$10 \mathrm{nM})$ [50]; MAP2K: $50 \mu \mathrm{M}$ PD98059 ( $\left.\mathrm{IC}_{50}: 2-7 \mu \mathrm{M}\right)$ 
[51]; MAP2K: $5 \mu \mathrm{M}$ U0126 ( $\left.\mathrm{IC}_{50}: 58-72 \mathrm{nM}\right)$ [52]; p38-MAPK: $5 \mu \mathrm{M}$ SB203580 ( $\mathrm{IC}_{50}: 0.5 \mu \mathrm{M}$, for AKT/ PKB 3-5 $\mu \mathrm{M})$ [53, 54]; PI3K- $\alpha$ : 100 nM GSK 1059625

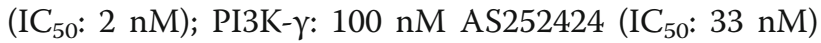
[55]; AKT/PKB: $10 \mu \mathrm{M}$ 10-DEBC $\left(\mathrm{IC}_{50}: 2 \mu \mathrm{M}\right)$ [56]; actin polymerisation: $10 \mu \mathrm{M}$ cytochalasin $\mathrm{D}\left(\mathrm{IC}_{50}\right.$ : $100 \mathrm{nM}$ ) [57] or $1 \mu \mathrm{M}$ latrunculin A [58]; adenyl cyclase (AC): $100 \mu \mathrm{M}$ SQ22536 (IC $50: 1.4-200 \mu \mathrm{M})$ [59] and NO-synthase (NOS): $100 \mu \mathrm{M}$ L-NAME ( $\left.\mathrm{IC}_{50}: 25 \mu \mathrm{M}\right)$.

In PCLS, all changes of the initial vessel area (IVA) were quantified in \% and indicated as "Change [\% of IVA]". Thus, an IVA $<100 \%$ indicates contraction and an IVA $>100 \%$ indicates relaxation. To compare the contractile effect of PDGF-BB in pre-treated vessels, the intraluminal area was defined after pre-treatment again as $100 \%$. In the graphs, all pre-treatments were indicated. The intraluminal area of PAs and PVs was monitored with a digital video camera (Leica Viscam 1280, Leica DFC 280). The images were analysed with Optimas 6.5 (Media Cybernetics, Bothell, WA).

\section{ELISAs}

To analyse cAMP, PVs were isolated out of tissue cores guided by their anatomical landmarks, e.g. the PAs accompany the airways and PV lies aside. PVs were incubated in medium, flushed with PDGF-BB (100 nM) and after 30 min frozen by liquid nitrogen. Cyclic AMP was quantified with ELISA-kits following the manufacturer's protocol. Samples/standards were acetylated for stabilisation. To measure cAMP, all samples were diluted 1:2 with $0.1 \mathrm{M}$ HCL. The ELISA was analysed at $405 \mathrm{nM}$ (GENIOS, Tecan, Switzerland).

To analyse prostacyclin (synonym: prostaglandine $\mathrm{I}_{2}$ $\left.\left(\mathrm{PGI}_{2}\right)\right)$ and thromboxane $\mathrm{A}_{2}\left(\mathrm{TXA}_{2}\right)$, IPL perfusate samples were obtained at 0,30 (before PDGF-BB was applied) or $120 \mathrm{~min}$ and stored at $-80{ }^{\circ} \mathrm{C}$. $\mathrm{PGI}_{2}$ and $\mathrm{TXA}_{2}$ are quickly metabolised, hence the metabolites 6-keto prostaglandin $\mathrm{F}_{1 \alpha}$ (6-keto $\mathrm{PGF}_{1 \alpha}$ ) and 11-dehydro $\mathrm{TXB}_{2}$ and 2,3-dinor $\left(\mathrm{TXB}_{2}\right)$ were measured to estimate the generation of $\mathrm{PGI}_{2}$ and $\mathrm{TXA}_{2}$, respectively. Prostaglandin metabolites were quantified with ELISA-kits following the manufacturer's protocol and measured at $412 \mathrm{nM}$ (GENIOS, Tecan, Switzerland).

\section{Chemicals}

PDGF-BB was provided by Peprotech (Hamburg, Germany). Imatinib mesylate, amlodipine, fasudile, calphostin $C$, indomethacin, SC51322, PF04418948, L798106, L161982, GSK 1059615, AS 252424, 10-DEBC and SQ22536 were purchased from Tocris Bioscience (Ellisville, Missouri, USA). Ponatinib was acquired from SelleckChem (Munich, Germany). SQ29548, RO-1138452, SU6668, SB203580, PD98059 and U0126 were acquired from Cayman Europe (via Biomol, Hamburg, Germany). The cAMP ELISA-kit was acquired from Enzo (Lörrach, Germany), whereas all ELISA-kits applied to quantify prostaglandin generation were acquired from Cayman Europe (via Biomol, Hamburg, Germany). L-Name, cytochalasin D, latrunculin A or standard laboratory chemicals were provided by Sigma (Steinheim, Germany).

\section{Statistical analysis}

Statistics were conducted using SAS software 9.3 (SAS Institute, Cary, North Carolina, USA) and GraphPad Prism 5.01 (GraphPad, La Jolla, USA). The data in Fig. $6 \mathrm{a} / \mathrm{c}$ were analysed by the Wilcoxon signed rank test (matched pairs), whereas the data in Fig. 6b/dor Fig. 8c were analysed by the Mann-Whitney U test (no matched paired). All other data were analysed using a linear mixed model analysis (LMM) with the covariance structure AR(1). All $p$-values were adjusted for multiple comparisons by the false discovery rate and are presented as mean \pm SEM; $n$ indicates the numbers of animals. $P<$ 0.05 was considered as significant.

\section{Results}

We studied the pulmonary vascular effects of PDGF-BB using healthy lungs (IPL/PCLS) from GPs. Beyond that, we studied the downstream-signalling of PDGF-BB-induced contraction in PVs of GPs.

\section{IPL: Effect of PDGF-BB on the pulmonary vascular tone}

Perfusion of PDGF-BB (final concentration in the buffer: $10 \mathrm{nM})$ increased $\mathrm{P}_{\mathrm{PA}}$ up to $116 \%(p<0.05)$, whereas $\mathrm{P}_{\mathrm{PA}}$ remained stable over $140 \mathrm{~min}$ in untreated control lungs (Fig. 2a). Pre-treatment with perfused imatinib (final concentration in the buffer: $10 \mu \mathrm{M}$ ) completely prevented the PDGF-BB-related increase of $\mathrm{P}_{\mathrm{PA}}(p<$ 0.05 ) (Fig. 2a) and even decreased $\mathrm{P}_{\mathrm{PA}}$ compared to baseline values $(p<0.001)$. Pre-treatment with nebulised imatinib also prevented the PDGF-BB-induced increase of $\mathrm{P}_{\mathrm{PA}}(p<0.05)$ (Fig. 2a). In addition, the soley perfusion of imatinib significantly decreased $\mathrm{P}_{\mathrm{PA}}$ compared to baseline values $(\mathrm{p}<0.001)$ (Fig. 2a).

Perfusion of PDGF-BB (final concentration in the buffer: $10 \mathrm{nM})$ increased $\mathrm{P}_{\text {cap }}$ up to $193 \%(\mathrm{p}<0.001)$ compared to control lungs and to baseline values (Fig. $2 \mathrm{~b}$ ). According to the effects on $\mathrm{P}_{\mathrm{PA}}$, the PDGF-BB-induced increase of $\mathrm{P}_{\text {cap }}$ was completely prevented $(\mathrm{p}<0.001)$, if the lungs were pre-treated with perfused or nebulised imatinib (Fig. 2b). Further, perfusion of imatinib lowered $\mathrm{P}_{\text {cap }}$, at time points 60,100 or $120 \mathrm{~min}$ (for all: 0.04) (Fig. 2b). Neither perfusion of PDGF-BB, nor perfusion of imatinib affected anyhow $R_{\text {pre }}$ (Fig. 2c).

Perfusion of PDGF-BB significantly increased $\mathrm{R}_{\text {post }}(p$ $<0.001)$. This effect was completely prevented, if lungs were pre-treated with imatinib $(p<0.001)$, either perfused or nebulised. Further, perfusion of imatinib alone 

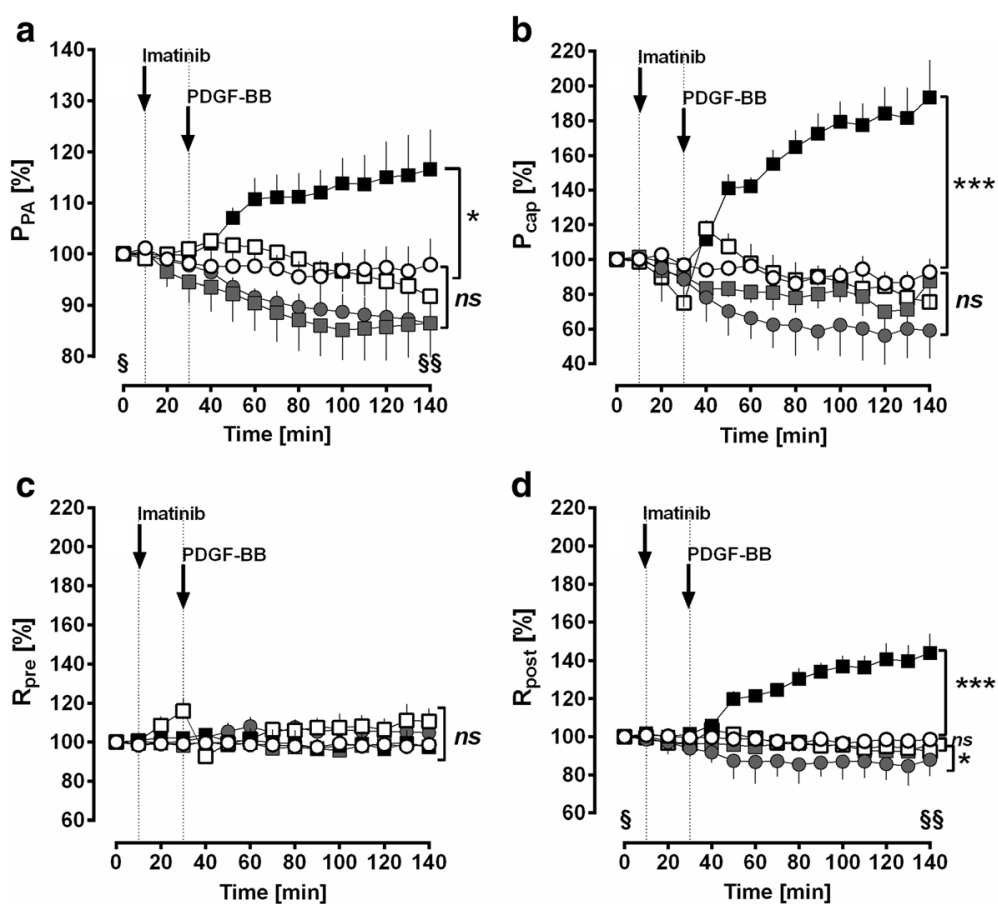

Fig. 2 IPL: Effect of PDGF-BB on the pulmonary vascular tone. a Effect of PDGF-BB on PPA. $\mathbf{b}$ Effect of PDGF-BB on Pcap. $\mathbf{c}$ Effect of PDGF-BB on $R_{\text {pre. }} \mathbf{d}$ Effect of PDGF-BB on R post. For all: (o) control $(n=7)$; $(\mathbf{a})$ PDGF-BB $(n=7)$; (grey circle) imatinib $(n=7)$; (grey square) perfused imatinib / PDGF-BB $(n=7) ;(\square)$ nebulised imatinib / PDGF-BB $(n=6)$; a-d Statistics was performed by a LMM. $P<0.05$ are considered as significant: ${ }^{*} p<0.05$,

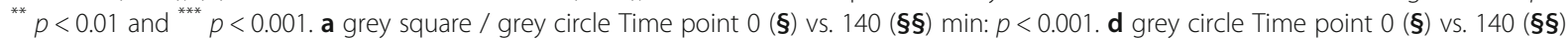
$\min : p<0.05$

decreased $\mathrm{R}_{\text {post }}(p<0.05)$ compared to control lungs and to baseline values (Fig. $2 \mathrm{~d}$ ). The addition of PDGF-BB did not alter $\mathrm{P}_{\mathrm{LA}}$ (data not shown).

\section{PCLS: PDGF-BB contracts PAs and PVs via activation of PDGFR- $\beta$}

In IPLs, PDGF-BB contracted the pulmonary vascular bed and this was preventable by the TKI imatinib (Fig. 2). Next, we tried to find out in PCLS if PDGF-BB contracts PAs and if this contraction predominantly depends on PDGFR- $\beta$, as it was shown for PVs (Fig. 3a) [7]. PDGF-BB contracted PAs up to $87 \%$ of IVA $(p<0.05)$ and this contraction was prevented, if PCLS were pre-treated with the PDGFR- $\beta$ inhibitor SU6668 $\quad(p<0.01)$, whereas pre-treatment with the PDGFR- $\alpha$ inhibitor ponatinib had no effect (Fig. 3b). In PVs, PDGF-BB-induced contraction was stronger than in PAs $(p<0.01$, Fig. 3c).

\section{PCLS: Mechanisms beyond PDGF-BB induced contraction in PVs}

To get insights if there is a link between PDGF-BB-induced contraction and the pathogenesis of $\mathrm{PH}$, we focused the mechanisms beyond PDGF-BB-induced contraction. Due to the weak contractile effect of PDGF-BB in PAs; we studied PDGF-BB downstream-signalling in PVs.
The role of calcium in PDGF-BB-induced contraction

PVs were pre-treated for $60 \mathrm{~min}$ with $100 \mathrm{nM}$ amlodipine (L-Type $\mathrm{Ca}^{2+}$-channels), $10 \mu \mathrm{M}$ fasudile (Rho kinase inhibitor) or $5 \mu \mathrm{M}$ calphostin $\mathrm{C}$ (PKC) prior to the application of $100 \mathrm{nM}$ PDGF-BB. Amlodipine significantly reduced the contractile effect of PDGF-BB ( $\mathrm{p}<0.05)$ (Fig. 4a), whereas fasudile (Fig. 4b) or calphostin $\mathrm{C}$ (Fig. 4c) were without significant effect ( $p>0.05$ for both).

\section{The role of prostaglandins in PDGF-BB-induced contraction}

Next, we studied, whether the contractile effect of PDGF-BB is mediated via contractile prostaglandins. PCLS were pre-treated with the non-selective cyclooxygenase-inhibitor indomethacin $(3 \mu \mathrm{M})$, with the $\mathrm{EP}_{1}$-receptor antagonist SC51322 $(1 \mu \mathrm{M})$, with the $\mathrm{EP}_{2}$-receptor antagonist PF04418948 $(1 \mu \mathrm{M})$, with the $\mathrm{EP}_{3}$-receptor antagonist L798106 $(1 \mu \mathrm{M})$, with the $\mathrm{EP}_{4}$-receptor antagonist L161982 $(1 \mu \mathrm{M})$, with the TP-receptor antagonist SQ29548 $(10 \mu \mathrm{M})$ and with the IP-receptor antagonist RO-1138454 $(1 \mu \mathrm{M})$. Inhibition of prostaglandin synthesis (indomethacin) did not significantly alter PDGF-BB-induced contraction (Fig. 5a), although the sustained effect of PDGF-BB appeared to be reduced. PDGF-BB-induced contraction was significantly reduced, if $\mathrm{EP}_{1}$-receptors $(p<0.01$; Fig. $5 \mathrm{~b}), \mathrm{EP}_{3}$-receptors $(p$ $<0.001$; Fig. $5 \mathrm{~b})$ or TP-receptors $(p<0.01$; Fig. 5 e) were 


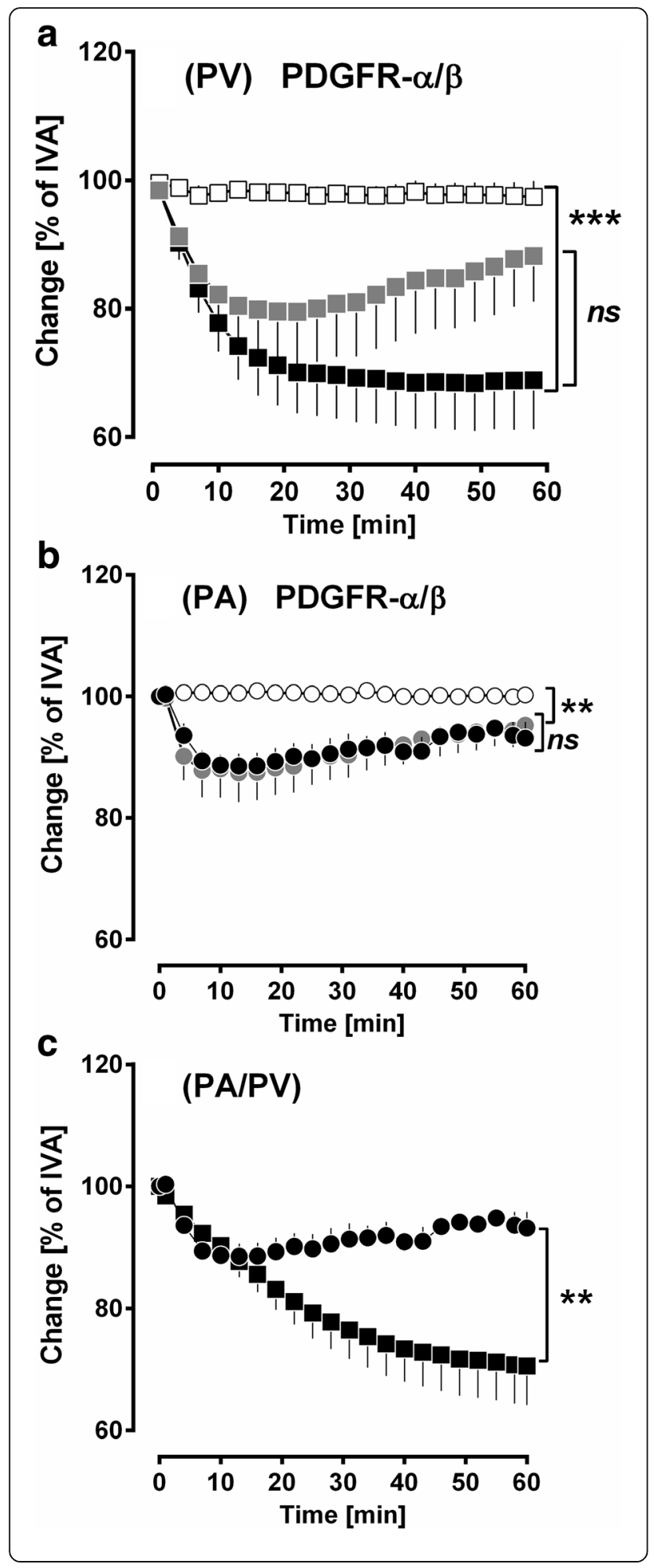

blocked. In contrast, inhibition of $\mathrm{EP}_{4}$-receptors (Fig. 5d) only attenuated PDGF-BB-induced contraction from time point $45 \mathrm{~min}$, whereas inhibition of $\mathrm{EP}_{2}$-receptors (Fig. $5 \mathrm{c}$ ) or IP-receptors (Fig. 5f) did not affect the maximal contractile effect of PDGF-BB. However, pre-treatment with the
Fig. 3 PCLS: PDGF-BB contracts PAs and PVs via activation of PDGFR- $\beta$. a PDGF-BB contracts PVs: (ם) no pre-treatment / $100 \mathrm{nM}$ PDGF-BB $(n=7)$; (grey square) 100 nM ponatinib / 100 nM PDGF-BB $(n=7) ;(\square) 5 \mu \mathrm{M}$ SU6668 / $100 \mathrm{nM}$ PDGF-BB $(n=7)$. b The contractile effect of PDGF-BB in PAs: $\bullet$ no pre-treatment / 100 nM PDGF-BB ( $n$ =7); (grey circle) $100 \mathrm{nM}$ ponatinib / $100 \mathrm{nM}$ PDGF-BB $(n=7)$; (0) 5 4M SU6668 / 100 nM PDGF-BB $(n=7)$. c PDGF-BB-induced contraction in PAs/PVs: $(\bullet)$ PAs: 100 nM PDGF-BB $(n=7)$; (घ) PVs: 100 nM PDGF-BB $(n=7)$. a-c Statistics was performed by a LMM. $P<$ 0.05 are considered as significant: ${ }^{*} p<0.05,{ }^{* *} p<0.01$ and $p<0.001$

IP-receptor antagonist RO-1138454 strongly contracted PVs to $75.5 \%$ of IVA $(p<0.001$; data not shown). Finally, inhibition of $\mathrm{EP}_{3}$-receptors (Fig. $5 \mathrm{~b}$ ) was most potent and nearly completely prevented PDGF-BB-induced contraction.

In IPL-perfusate samples, we studied the effect of PDGF-BB on the generation of prostaglandins, e.g. $\mathrm{TXB}_{2}$ for $\mathrm{TXA}_{2}$ and 6-keto $\mathrm{PGF}_{1 \alpha}$ for $\mathrm{PGI}_{2}$ (Fig. 6). After 120 min of perfusion, PDGF-BB enhanced $\mathrm{TXB}_{2}$ compared to basic values $(p<0.05$; Fig. 6a). Further at $120 \mathrm{~min}, \mathrm{TXB}_{2}$ was significantly increased compared to 1) the control, 2) the imatinib/PDGF-BB and 3) the imatinib group ( $<<0.05$; Fig. $6 \mathrm{~b})$, whereas at 0 or $30 \mathrm{~min}$, the four treatment groups did not differ (Fig. 6b). In contrast, the $\mathrm{PGI}_{2}$-metabolite 6-keto $\mathrm{PGF}_{1 \alpha}$ was in all groups significantly increased $(p<0.05)$ in dependence to the perfusion time (Fig. 6c). At 120 min, 6-keto PGF ${ }_{1 \alpha}$ reached a level of $341 \mathrm{pg} / \mathrm{ml}$ in the PDGF-BB group compared to $193 \mathrm{pg} / \mathrm{ml}$ in the control group $(p>0.05)$ and to $124 \mathrm{pg} / \mathrm{ml}$ in the imatinib/PDGF-BB group $(\mathrm{p}<$ 0.05; Fig. 6d). Hence, 6-keto $\mathrm{PGF}_{1 \alpha}$ was significantly lower, if IPLs were pre-treated with imatinib compared to PDGF-BB alone, although PDGF-BB did not significantly increase 6-keto $\mathrm{PGF}_{1 \alpha}$ compared to the control group. With regard to 6-keto $\mathrm{PGF}_{1 \alpha}$, no differences were found at 0 or $30 \mathrm{~min}$ (Fig. 6d).

\section{MAPK-pathway and PI3K-a/ $\gamma$ and AKT/PKB}

Next, we studied if the PDGF-BB downstream-signalling involved in proliferation [3] also contributes to PDGF-BB-induced contraction. Therefore, we inhibited cellular pathways such as MAP2K (5 $\mu \mathrm{M}$ U0126 / $50 \mu \mathrm{M}$ PD98059), p-38 MAPK (5 $\mu \mathrm{M}$ SB203580), PI3K- $\alpha$ (100 nM GSK 1059625), PI3K- $\gamma \quad(100$ nM AS252424) and AKT/PKB (10 $\mu \mathrm{M}$ DEBC). Inhibition of MAP2K $(p<0.05, p<0.001$; Fig. 7a), p38-MAPK $(\mathrm{p}<$ 0.05 ; Fig. $7 \mathrm{~b})$, AKT/PKB (p $<0.001$; Fig. 7e), PI3K- $\alpha(p<$ 0.5 ; Fig. $7 \mathrm{c})$ and PI3K- $\gamma(\mathrm{p}<0.05)$ reduced the contractile effect of PDGF-BB (Fig. 7d).

\section{PDGF-BB-induced generation of relaxant mediators}

The data from Fig. 7a/e reveal weak relaxation due to PDGF-BB leading to an IVA $>100 \%$. Together with the observations that some PVs contract to less than $80 \%$ of 


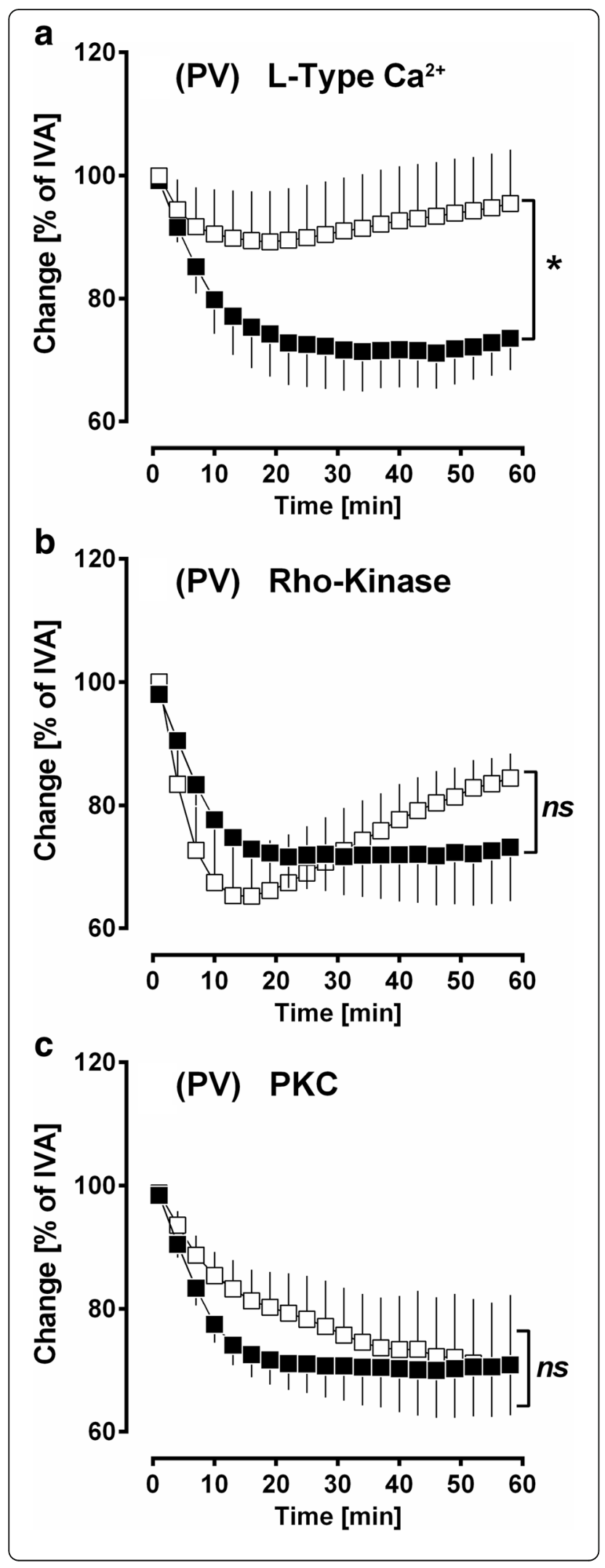

Fig. 4 PCLS: The role of $\mathrm{Ca}^{2+}$ in PDGF-BB-induced contraction in PVs. a PDGF-BB-induced contraction depends on the activation of LType $\mathrm{Ca}^{2+}$-channels: (घ) no pre-treatment / 100 nM PDGF-BB $(n=8)$; () $100 \mathrm{nM}$ amlodipine / $100 \mathrm{nM}$ PDGF-BB $(n=8)$. b PDGF-BBinduced contraction does not depend on the activation of Rho Kinase: (घ) no pre-treatment / 100 nM PDGF-BB $(n=8)$; (口) $10 \mu \mathrm{M}$ fasudile / 100 nM PDGF-BB $(n=8)$. C) PDGF-BB-induced contraction does not depend on the activation of protein kinase C (PKC): (घ) no pre-treatment / 100 nM PDGF-BB $(n=8)$; ( $\square) 5 \mu \mathrm{M}$ calphostin C / 100 nM PDGF-BB $(n=8)$. a-c Statistics was performed by a LMM. $\mathrm{P}<$ 0.05 are considered as significant: ${ }^{*} p<0.05,{ }^{* *} p<0.01$ and $p<0.001$

IVA (Fig. 7a; $p=0.003$ ), the idea was obvious that PDGF-BB downstream-signalling might involve relaxant mediators different from $\mathrm{PGI}_{2}$ (Fig. 6c/d), e.g. cAMP or NO. To study this issue, PVs were pre-treated with the AC-inhibitor SQ22536 or with the endothelial NOS-inhibitor L-NAME prior to the application of PDGF-BB. Inhibition of cAMP-generation (SQ22536) increased the contractile effect of PDGF-BB until time point 35 min $(\mathrm{p}<0.001)$ (Fig. 8a), whereas inhibition of endothelial NOS (eNOS) only slightly enhanced it (Fig. 8b), as this increase only reached statistical significance between the time points 30-45 min $(p<0.05$; Fig. 8b). Further, $100 \mathrm{nM}$ PDGF-BB increased cAMP $(p<$ 0.001 ) in PVs (Fig. 8c) suggesting that PDGF-BB-induced generation of cAMP influences the pulmonary venous tone, whereas PDGF-BB-related NO-synthesis appears to play a minor role in PVs.

The role of actin polymerisation in PDGF-BB-induced contraction

PDGF-BB-induced contraction appears to depend on complex intracellular pathways. Next, we analysed the role of actin polymerisation by $10 \mu \mathrm{M}$ cytochalasin $\mathrm{D}$ or $1 \mu \mathrm{M}$ latrunculin $\mathrm{A}$. Inhibition of actin polymerisation significantly lowered the contractile effect of PDGF-BB, as indicated for cytochalasin $\mathrm{D}(p<0.001$; Fig. 9a) and latrunculin A ( $p<0.05$; Fig. 9b).

\section{Discussion}

PDGF and PDGFR play a critical role within the remodelling in $\mathrm{PH}[1,2]$. We show that PDGF-BB contracts the pulmonary vascular bed of GPs via activation of PDGFR- $\beta$. In PVs, PDGF-BB-induced contraction depends on L-Type $\mathrm{Ca}^{2+}$-channels, PI3K- $\alpha / \gamma$, MAPK- and AKT/PKB-signalling and actin remodelling. Beyond that, stimulation of $\mathrm{EP}_{1 / 3^{-}}$or TP-receptors plays a significant role in PDGF-BB-induced contraction, whereas stimulation of IP-receptors is not relevant. In addition, PVs treated with PDGF-BB show increased cAMP levels which do not appear to rely on $\mathrm{PGI}_{2}$.

Effects of PDGF-BB on the pulmonary vascular bed In the IPL, recirculating perfusion of $10 \mathrm{nM}$ PDGF-BB significantly enhanced $\mathrm{P}_{\mathrm{PA}}$ up to $116 \%$ (Fig. 2a). These 

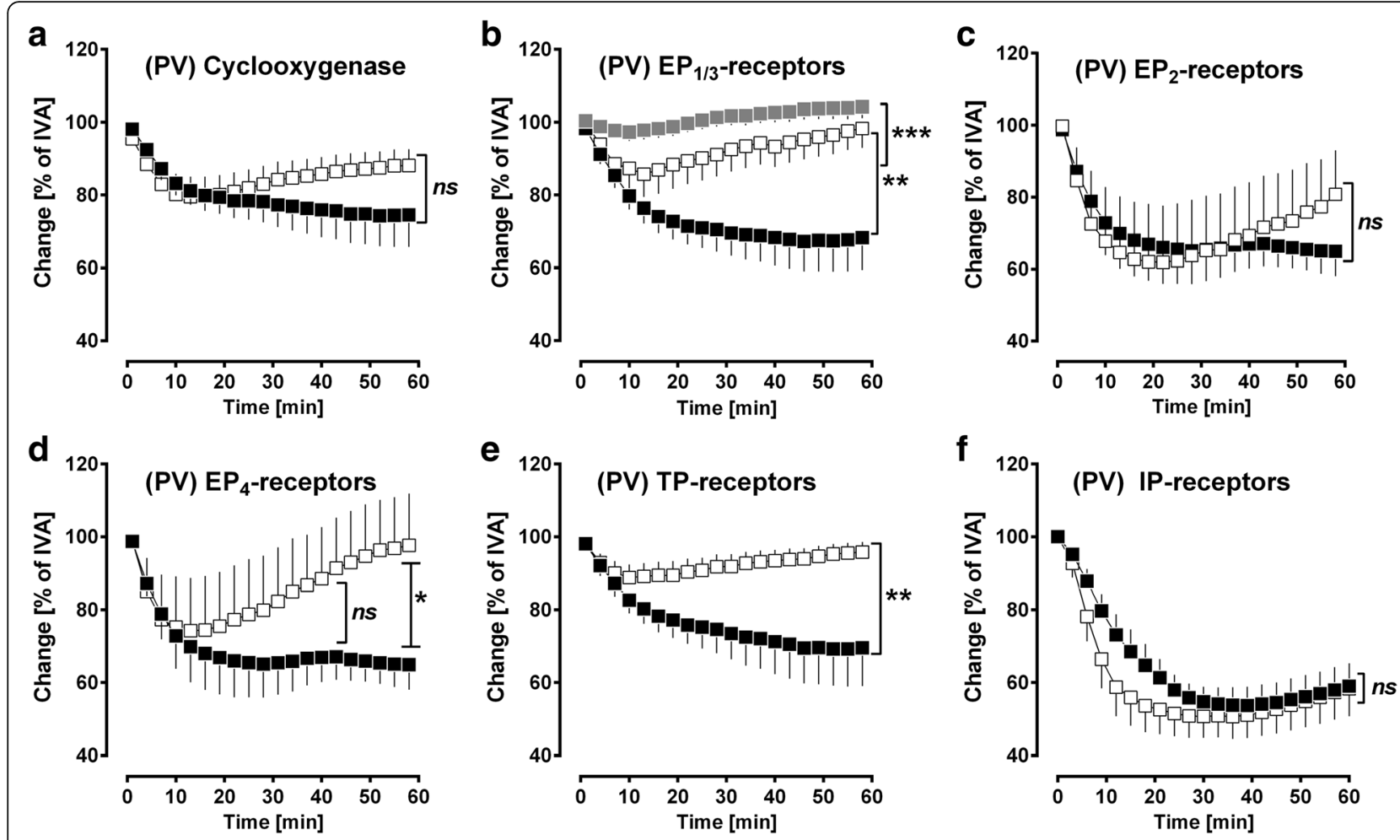

Fig. 5 PCLS: The role of prostaglandins in PDGF-BB-induced contraction in PVs. a Effect of inhibited cyclooxygenase on PDGF-BB-induced contraction: ( $\mathbf{\square})$ no pre-treatment / 100 nM PDGF-BB $(n=8)$; () $3 \mu \mathrm{M}$ indomethacin / $100 \mathrm{nM}$ PDGF-BB $(n=8)$. b PDGF-BB-induced contraction is

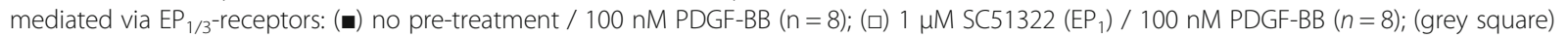

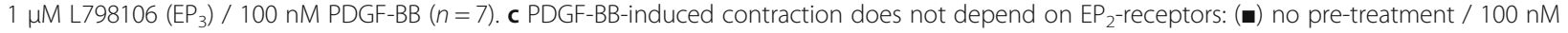

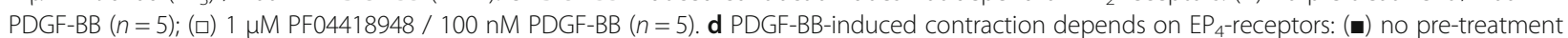
/ 100 nM PDGF-BB ( $n=5)$; ( $($ ) 1 HM L161982 / 100 nM PDGF-BB ( $n=5)$. e PDGF-BB-induced contraction depends on TP-receptors: ( $\mathbf{m})$ no pretreatment / 100 nM PDGF-BB ( $n=7$ ); ( $\square) 10$ MM SQ29548 / 100 nM PDGF-BB ( $n=7)$. f PDGF-BB-induced contraction does not depend on IPreceptors: ( $\mathbf{\square})$ no pre-treatment / 100 nM PDGF-BB $(n=4)$; ( $\square) 1 \mu$ M RO-1138452 / 100 nM PDGF-BB $(n=4)$. a-f Statistics was performed by a LMM. $P<0.05$ are considered as significant: ${ }^{*} p<0.05,{ }^{* *} p<0.01$ or ${ }^{* * *} p<0.001$

results confirmed those from PCLS; where $100 \mathrm{nM}$ PDGF-BB contracted PAs up to $87 \%$ of IVA (Fig. 3b). According to the Hagen-Poiseuille law, the resistance increases 16 fold, if the radius is splitted in half. Hence, $\mathrm{P}_{\mathrm{PA}}$ would have increased even above $116 \%$, if lungs were perfused with $100 \mathrm{nM}$ PDGF-BB. Further in the IPL, PDGF-BB-induced alteration of the vascular tone is detected even at lower concentrations compared to PCLS. This is supported by the fact that $10 \mathrm{nM}$ PDGF-BB did not contract GPs' PAs in PCLS (data not shown), whereas $10 \mathrm{nM}$ PDGF-BB enhanced $\mathrm{P}_{\mathrm{PA}}$ to $116 \%$ in the IPL (Fig. 2a). In contrast to these results, PDGF-BB did not alter $R_{\text {pre }}$ (Fig. 2c) indicating a minor effect on the cavine precapillary pulmonary vascular bed. Possible reasons for this observation might be 1) a lower receptor density; 2) a varying receptor equipment with reduced sensitivity. Most probably, our results regarding the effect of PDGF-BB on $\mathrm{R}_{\text {pre }}$ are not transferable to the human situation, as small human PAs are equipped with PDGFR- $\beta$ [1]. In general, GPs' PCLS allow to study more central pulmonary vessel, but do not represent the precapillary part of the pulmonary circulation [13]. In contrast, the IPL allows addressing the entire pulmonary vascular bed (except central PVs); particularly, it enables to determine the segmental vascular resistance $\left(R_{\text {pre }} /\right.$ $R_{\text {post }}$ ) by the double occlusion method $[7,13,14]$. Beyond PDGF-BB-induced pulmonary arterial contraction, PDGF-BB increased $\mathrm{P}_{\text {cap }}$ (Fig. 2b) and $\mathrm{R}_{\text {post }}$ (Fig. 2d) up to 200 and $140 \%$ of baseline values, respectively. Further, PDGF-BB contracted central PVs from GPs up to $70 \%$ (Fig. 3a).

Hence, our GP' data from both models suggest that PDGF-BB exerts significant contraction along the pulmonary vascular bed and give strong evidence that PDGF-BB-induced contraction is accentuated in the pulmonary venous system PVs (Fig. 2; Fig. 3). This result is of high clinical relevance, as the pulmonary venous bed contributes about $40 \%$ to pulmonary vascular resistance (PVR) [60] and plays a major role in PH due to left heart disease [61], the most common cause of $\mathrm{PH}[62,63]$. 
a

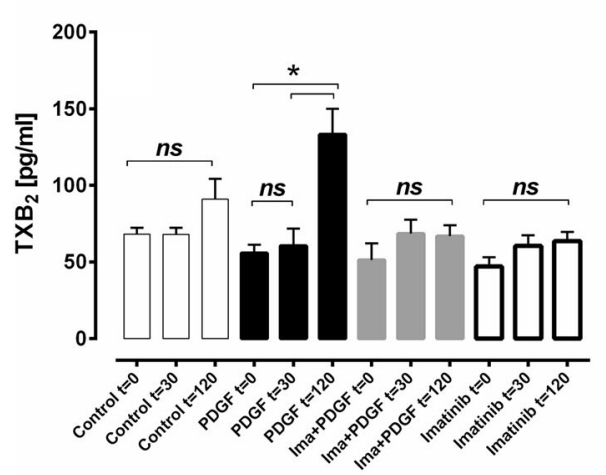

C

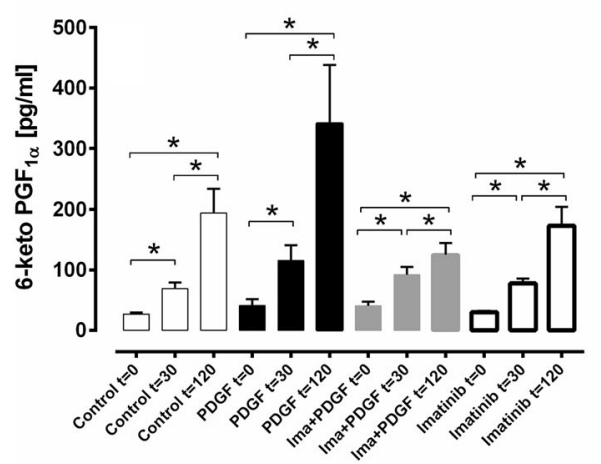

b

TXA $_{2}$-metabolites

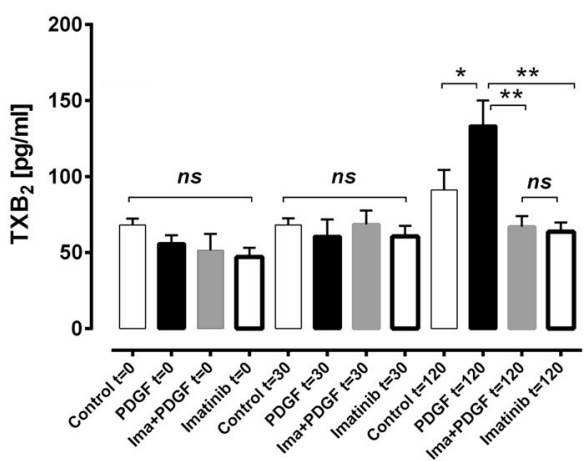

d

$\mathrm{PGI}_{2}$-metabolites

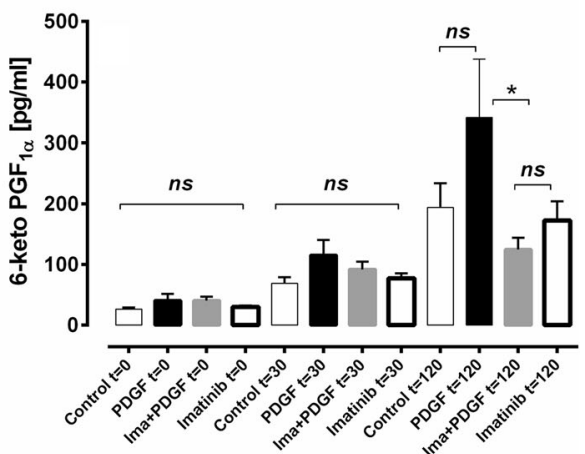

Fig. 6 The effect of PDGF-BB on $T_{X B_{2}}$ and 6-keto $\mathrm{PGF}_{1 \mathrm{a}}$ a $\mathrm{TXB}_{2}$-generation in dependence of the perfusion time. $\mathbf{b}$ Comparison of $\mathrm{TXB}_{2}-$ generation within the groups at the same time. $\mathbf{c} 6-$ keto PGF$_{10}$-generation in dependence of the perfusion time. $\mathbf{d}$ Comparison of 6-keto PGF ${ }_{1 a^{-}}$ generation within the groups at the same time. For all ( $\square$ ) control $(n=6)$; $(\mathbf{\square})$ perfusion with PDGF-BB $(n=6)$; (grey square) perfusion with imatinib / PDGF-BB $(n=6)$; ( $\square$ ) perfusion with imatinib $(n=6)$. a/c Statistics was performed by the Wilcoxon signed ranked test. b/d Statistics was performed by the Mann-Whitney $U$ test. $P<0.05$ are considered as significant: ${ }^{*} p<0.05$ and ${ }^{* *} p<0.01$

\section{PDGF-BB contracts the pulmonary vascular bed via activation of PDGFR- $\beta$}

PDGF-BB-induced contraction of the pulmonary vascular bed was completely prevented if IPLs (Fig. 2) were pre-treated with the PDGFR- $\alpha / \beta$ inhibitor imatinib, either perfused or nebulised; indicating that PDGF-BB-induced contraction specifically relies on the activation of PDGFR- $\alpha / \beta$. With regard to GPs' PVs, we recently showed that PDGF-BB-induced contraction mainly depends on the activation of PDGFR- $\beta$ (Fig. 3a), whereas activation of PDGFR- $\alpha$ only plays a minor role [7]. In this work, we validated this also for GPs' PAs as we found that inhibition of PDGFR- $\beta$ (SU6668) completely prevented PDGF-BB-induced contraction of PAs (Fig. 3b) and inhibition of PDGFR- $\alpha$ (ponatinib) had no effect (Fig. 3b). In the IPL, perfusion of imatinib did not only prevent the PDGF-BB-induced increase of $\mathrm{P}_{\mathrm{PA}}, \mathrm{P}_{\text {cap }}$ and $\mathrm{R}_{\text {post }}$, but also decreased $\mathrm{P}_{\mathrm{PA}}, \mathrm{R}_{\text {post }}$ and in part $\mathrm{P}_{\text {cap }}$ (time points 90 and $110 \mathrm{~min}$ after addition) compared to untreated control lungs. These data suggest the existence of endogenously produced PDGF-BB and the permanent activation of PDGFR.

\section{Mechanisms beyond PDGF-BB induced contraction}

After identification of PDGF in the seventies, PDGF-BB-induced contraction [8-10, 64] and relaxation $[11,12]$ was proven in systemic arteries. Afterwards, the vascular effects of PDGF disappeared in the background and research focused on the proliferative effects of PDGF $[1,2]$ leading to the introduction of TKIs in the therapy of $\mathrm{PH}[2,4,65]$. With this regard, TKI-induced relaxation has been uncovered [5-7] and the contractile effects of PDGF-BB have been proven in PVs [7]. Thus, it becomes apparent that PDGF-BB promotes aside proliferation also contraction of $\mathrm{PAs} / \mathrm{PVs}$, both promoting the progress of $\mathrm{PH}$. Therefore we studied the mechanisms beyond the contractile effect of PDGF-BB in GPs' PVs.

\section{The role of calcium in PDGF-BB-induced contraction} In PVs, PDGF-BB-induced contraction depended on the activation of L-Type $\mathrm{Ca}^{2+}$-channels (Fig. 4a), whereas $\mathrm{Ca}^{2}$ ${ }^{+}$-sensitisation did not play a role, as inhibition of Rho-Kinase or PKC did not alter PDGF-BB-induced contraction (Fig. 4b/c). In line with our results, PDGF-AB or 


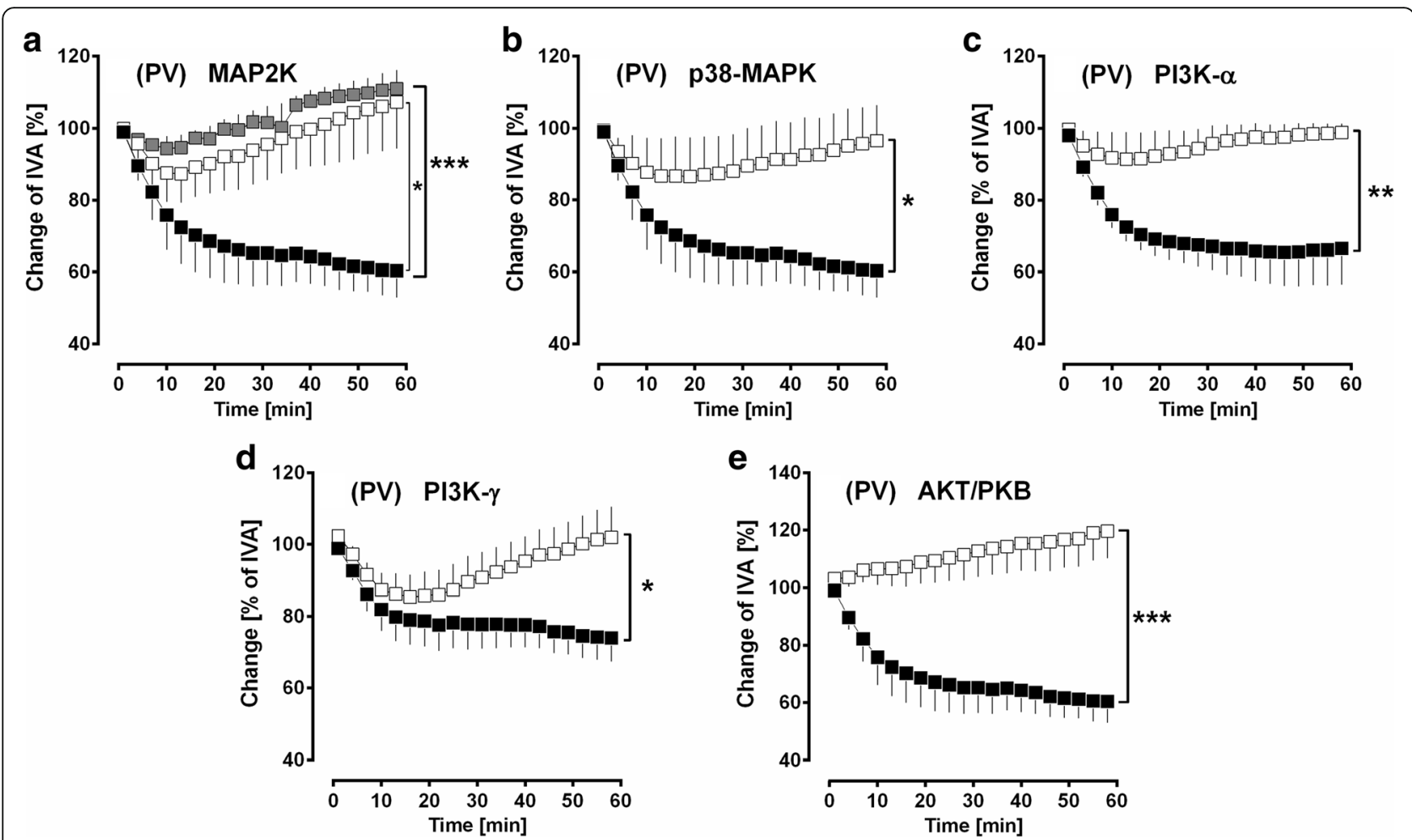

Fig. 7 PCLS: PDGFR downstream-signalling: MAPK- and PI3K/AKT/PKB-pathway in PVs. a PDGF-BB-induced contraction depends on MAP2K: (-) no

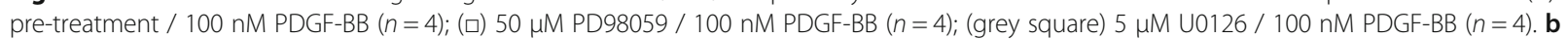

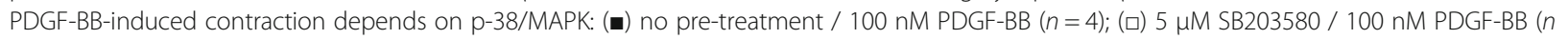

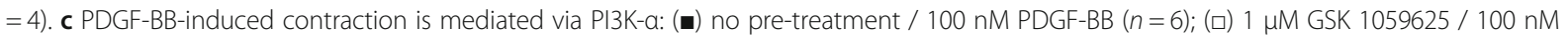
PDGF-BB $(n=6)$. d PDGF-BB-induced contraction does not interact with PI3K- $\gamma$ : ( $\mathbf{\square})$ no pre-treatment / 100 nM PDGF-BB $(n=5)$; ( $\square) 1 \mu \mathrm{M}$ AS252424 / $100 \mathrm{nM}$ PDGF-BB $(n=5)$. e PDGF-BB-induced contraction depends on the AKT/PKB signalling: ( $\mathbf{m})$ no pre-treatment / $100 \mathrm{nM}$ PDGF-BB $(n=4)$; $\left(\square 10 \mu \mathrm{M}\right.$ 10-DEBC / $100 \mathrm{nM}$ PDGF-BB $(n=4)$. a-e) Statistics was performed by a LMM. $P<0.05$ are considered as significant: ${ }^{*} p<0.05,{ }^{* *} p$ $<0.01$ and $^{* * *} p<0.001$

PDGF-BB contract extra pulmonary vessels in a calcium dependent manner $[8-10,64,66]$ and vice versa, TKIs modulate the activity of L-Type $\mathrm{Ca}^{2+}$-channels in portal veins $[67,68]$. Anyhow, differences exist within the PDGF dimers AA, AB or BB; e.g. Sachinidis et al. [10] reported in rats' aortic rings that $\mathrm{PDGF}-\mathrm{BB}$ contracts stronger and rises intracellular calcium more potently than PDGF-AB, whereas PDGF-AA acts only poorly contractile and does not rise intracellular calcium [10]. In rat aortic smooth muscle cells (SMCs), the same group $[10,69]$ found that PDGF-AA potently stimulates PKC, whereas PDGF-BB activates PKC only in a minor degree. These findings suggest that PDGF-AA rather acts via $\mathrm{Ca}^{2+}$-sensitisation, whereas PDGF-BB mainly exerts contraction via the increase of calcium. Moreover, with regard to tone or endothelial barrier, pulmonary and systemic vessels are diversely regulated [70]. This circumstance might also explain contrasting results.

The role of prostaglandins in PDGF-BB-induced contraction

So far, it is unknown, if prostaglandins mediate the contractile effect of PDGF-BB in pulmonary vessel. Although,
PDGFR downstream-signalling is linked to the generation of prostaglandins [71-73] and prostaglandin receptors, e.g. TP- or $\mathrm{EP}_{1 / 3}$-receptors are involved within the regulation of the tone of human PAs [74] and PVs [75, 76].

Now, our data reveal that PDGF-BB-induced contraction goes ahead with the activation of TP-receptors, as 1) inhibition of TP-receptors strongly reduced the contractile effect of PDGF-BB and as 2) $\mathrm{TXB}_{2}$, the inactive metabolite of $\mathrm{TXA}_{2}$ was significantly enhanced in PDGF-BB perfused lungs. TXA 2 acts as a potent vasoconstrictor and highly contributes to increased vascular tone in $\mathrm{PH}$ [77-79]. TP-receptors represent G-Protein-coupled receptors (GPCR) which are mainly coupled to $G_{\alpha q / 11}$ and $G_{\alpha 12 / 13}$, but also to $G_{\alpha s / i}, G_{h}$ and $\mathrm{G}_{\beta \gamma}$; finally their stimulation leads to the regulation of phospholipase $\mathrm{C}$ (PLC)/inositol trisphosphate $\left(\mathrm{IP}_{3}\right) / \mathrm{cal}$ cium, Rho and AC [80]. Beyond that, MAPK- and PI3K-signalling is also involved [80]. In line with our data, Sachinidis et al. [10] showed in systemic vessels that PDGF-BB leads to the generation of $\mathrm{TXA}_{2}$ which exerts as well as the TP-agonist U46619 a strong and long-lasting contraction along the pulmonary vascular 


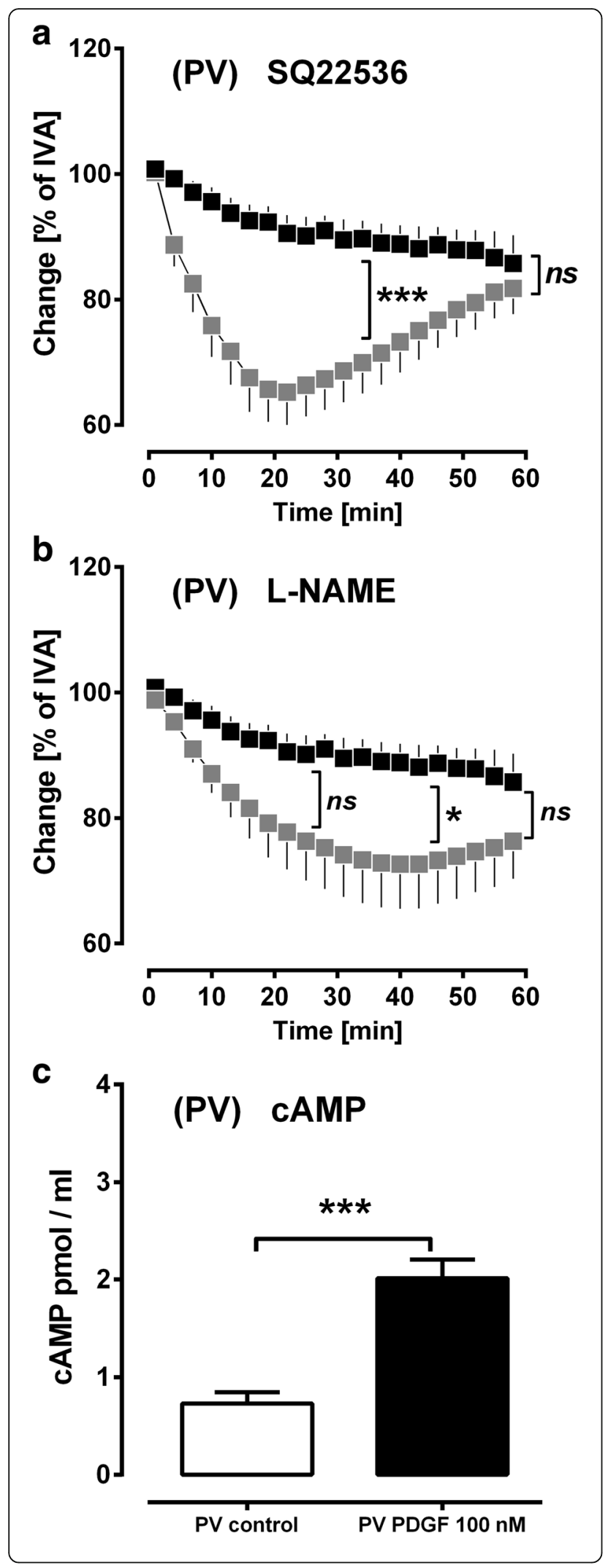

Fig. 8 Relevance of relaxant signalling cascades in PDGFR-signalling in PVs. a Role of CAMP in PDGFR-signalling: (- no pre-treatment / 100 nM PDGF-BB ( $n=10)$; (grey square) $100 \mu \mathrm{M}$ SQ22536/ 100 nM PDGF-BB $(n=10)$. b Role of NO in PDGFR-signalling: $(\mathbf{a})$ no pretreatment / 100 nM PDGF-BB $(n=10)$; (grey square) $100 \mu \mathrm{M}$ L-NAME / 100 nM PDGF-BB $(n=10)$. c PDGF-BB increases intracellular CAMP: ( $\square$ ) no PDGF-BB (control) $(n=10) ;(\mathbf{\square}) 100$ nM PDGF-BB $(n=11) \mathbf{a} / \mathbf{b}$ Statistics was performed by a LMM. C) Statistics was performed by the Mann-Whitney $U$ test. $P<0.05$ are considered as significant: ${ }^{*} P$ $<0.05,{ }^{* *} p<0.01$ and ${ }^{* * *} p<0.001$

bed [81-84]. Our data show no involvement of Rho/ PKC in PDGF-BB downstream-signalling. This is opposing to Murtha et al. [84] who showed in rabbits' pulmonary arterial rings that the contractile effect of $\mathrm{TXA}_{2}$ depends on PKC. Further, TP-receptors are coupled to $G_{\alpha 12 / 13}$, hence their stimulation should activate Rho [85], unless TP-receptors are primarily coupled to $G_{\alpha q / 11}[80]$. Notably, vasoconstrictors such as endothelin-1 or platelet-activating factor also mediate their contractile effect via the release of $\mathrm{TXA}_{2}[86,87]$.

Our results indicate that PDGF-BB-induced contraction goes ahead with the activation of $\mathrm{EP}_{1 / 3 / 4}$-receptors, whereas stimulation of $\mathrm{EP}_{2}$-receptors does not play a role (Fig. $5 \mathrm{c}$ ). Hence, $\mathrm{PGE}_{2}$ as the most widely produced prostaglandin of the body binding to $\mathrm{EP}_{1-4}$-receptors (GPCRs) [25] appears to be highly involved in PDGF-BB-induced contraction. $\mathrm{EP}_{1}$-receptors are coupled to $G_{\alpha q / 11}[25,88]$ and their activation triggers the intracellular increase of PLC, $\mathrm{IP}_{3}$ and calcium [88]. In contrast, $\mathrm{EP}_{3}$-receptors are mainly coupled to $\mathrm{G}_{\alpha \mathrm{i}}$ and their activation inhibits the $\mathrm{AC}$ leading to decreased cAMP-levels [25, 88]. Here, inhibition of $\mathrm{EP}_{3}$-receptors nearly completely prevented PDGF-BB-induced contraction, although inhibition of $\mathrm{EP}_{1}$ - or TP-receptors was also very effective in preventing the contractile effect of PDGF-BB. So, the question comes up if the $\mathrm{EP}_{3}$-receptor antagonist L798106 acts unspecific and also binds to $\mathrm{EP}_{1^{-}}$or TP-receptors. According to $\mathrm{IC}_{50}$ values, this is not the case [48]. However, the prominent effect of $\mathrm{EP}_{3}$-inhibition on PDGF-BB-induced contraction might be explainable by the consideration that $\mathrm{EP}_{3}$-inhibition may provoke an overwhelming cAMP-generation counteracting other contractile mediators activated by PDGF-BB. In general, $\mathrm{EP}_{3}$-agonists strongly contract human PAs [74]. Beyond that, they influence the progress of $\mathrm{PH}$, as $\mathrm{EP}_{3}$-receptor deficiency attenuates the expression of $\mathrm{PH}$ [89]. Aside $\mathrm{EP}_{1 / 3}$-receptors, $\mathrm{PGE}_{2}$ also activates $\mathrm{EP}_{2}$ - and $\mathrm{EP}_{4}$-receptors which are both coupled to $\mathrm{G}_{\alpha \mathrm{\alpha s}}$ leading to the activation of $\mathrm{AC}$, to the increase of cAMP and to reduced vessel tone [25, 88]. Moreover, $\mathrm{EP}_{4}$-receptors also couple to $\mathrm{G}_{\alpha \mathrm{i}}$ representing the counter player of $\mathrm{G}_{\mathrm{\alpha s}}[25,88]$. Here, inhibition of $\mathrm{EP}_{2}$-receptors did not enhance the contractile effect of PDGF-BB, inhibition of $\mathrm{EP}_{4}$-receptors reduced PDGF-BB-induced 

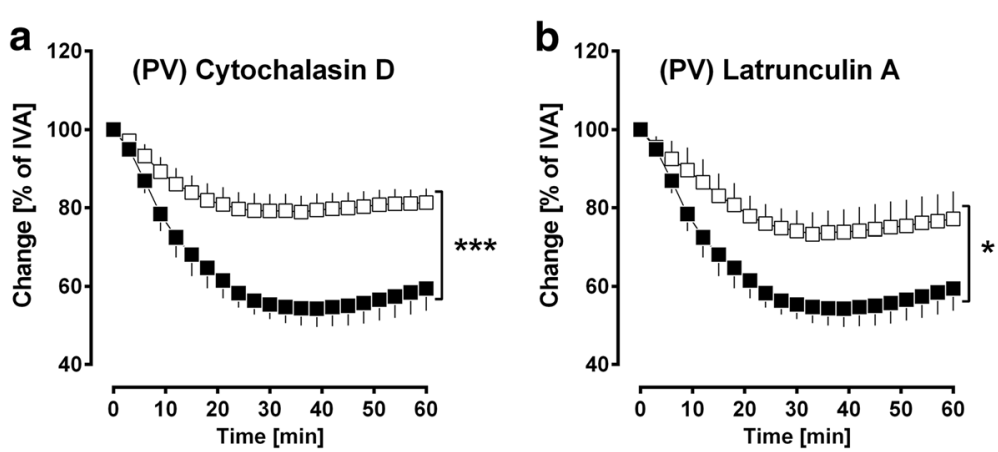

Fig. 9 The role of actin polymerisation in PDGF-BB-induced contraction. a. Inhibition of actin polymerisation by cytochalasin D: (-) no pretreatment / 100 nM PDGF-B ( $n=4)$; ( $($ ) $10 \mu \mathrm{M}$ cytochalasin D / 100 nM PDGF-BB $(n=4)$. b Inhibition of actin polymerisation by latrunculin A: ( no pre-treatment / 100 nM PDGF-BB $(n=4)$; () $1 \mu$ M latrunculin A / 100 nM PDGF-BB $(n=4)$. a/b Statistics was performed by a LMM. $P<0.05$ are considered as significant: ${ }^{*} p<0.05$ and ${ }^{* * *} p<0.001$

contraction and PVs treated with PDGF-BB showed increased cAMP-levels. These data suggest 1) a possible minor expression of $\mathrm{EP}_{2}$-receptors in GPs' PVs or 2) a possible dominant coupling of $\mathrm{EP}_{4}$-receptors to $\mathrm{G}_{\mathrm{\alpha i}}[90]$ which has been already reported in the hypoxic pulmonary arterial bed of the rat. In addition, although $\mathrm{EP}_{4}$-receptors appear to couple dominantly to $G_{\alpha i}$ ' $\mathrm{G}_{\mathrm{\alpha s}}$-coupling seems to be of relevance, as PDGF-BB significantly increased cAMP-levels in PVs. This idea is supported by the circumstance that $\mathrm{PGI}_{2}$, as a main source for cAMP [91] did not significantly increase due to PDGF-BB. Thus, the production of cAMP should derive from PDGF-BB-induced activation of prostaglandin receptors others than IP, but also coupled to $G_{\alpha s}$.

In general, the various prostaglandins mediate contraction or relaxation. In this work, $\mathrm{EP}_{1 / 3 / 4^{-}}$and TP-receptors reduced the contractile effect of PDGF-BB, whereas none of the inhibitors, including the IP-receptor antagonist RO-1138452, did increase PDGF-BB-induced contraction. At first glance, PDGF-BB-downstream-signalling appears to be dominated by the generation of contractile prostaglandins. At second view, this assumption is opposed, as inhibition of prostaglandin synthesis (indomethacin) did not significantly alter PDGF-BB-induced contraction (Fig. $5 \mathrm{a})$; a fact which suggests that PDGF-BB-dependent prostaglandin generation is well-balanced between contractile and relaxant ones. Further, inhibition of MAP2K- and AKT/PKB-signalling (Fig. 7a/e) unmasked a slight relaxant effect of PDGF-BB supporting the hypothesis that PDGFR-downstream-signalling is anyhow related to relaxant pathways. Our results indicate that $\mathrm{PGI}_{2}$ is of less relevance within the regulation of the pulmonary vascular tone by PDGF-BB, as 1) inhibition of IP-receptors did not enhance the contractile effect of PDGF-BB (Fig. 5f). 2) PDGF-BB did not increase $\mathrm{PGI}_{2}$ (Fig. 6c/d), though a trend appears to be evident which is enforced by the fact that pre-treatment with imatinib significantly lowered $\mathrm{PGI}_{2}$-levels compared to PDGF-BB perfusion alone. The observation that $\mathrm{PGI}_{2}$ increased time-dependently in the perfusate of all IPL-groups (Fig. 6c), including control lungs is explainable by the endothelial release of $\mathrm{PGI}_{2}$ counteracting the increased shear stress in perfused lungs $[92,93]$. In general, the release of $\mathrm{PGI}_{2}$ strongly depends on shear stress [94]. In contrast, in PCLS shear stress is hardly effective [95], hence time-dependent $\mathrm{PGI}_{2}$-release is not expected. However, we could show that basal $\mathrm{PGI}_{2}$-release should occur, as inhibition of IP-receptors increased the tone of PVs. Finally, our data indicate that PDGF-BB-induced $\mathrm{PGI}_{2}$-release is less relevant, although we cannot exclude that PDGF-BB potentiates anyhow the release of $\mathrm{PGI}_{2}$ due to shear stress. Our results are different from those of Yamawaki et al. [12] who proved that PDGF-BB relaxes rat mesenteric arteries in dependence to the release of $\mathrm{PGI}_{2}$. Finally, the role of PDGF-BB-induced $\mathrm{PGI}_{2}$-release might depend on the vessel localisation, e.g. pulmonary vessels versus systemic vessels and on the species.

In spite of the fact that PDGF-BB contracts GPs' PVs, the generation of relaxant mediators such as cAMP and cGMP plays a relevant role in PDGFR-downstream-signalling. 1) Inhibition of $\mathrm{AC}$ (Fig. 8a) enforced the contractile effect of PDGF-BB, 2) PVs treated with PDGF-BB had higher cAMP-levels than control PVs (Fig. 8c) and 3) inhibition of eNOS slightly enforced the contractile effect of PDGF-BB (Fig. 8b). Our results are supported by those of Graves et al. [96] who found in human arterial SMCs that PDGF-BB downstream-signalling goes ahead with the generation of cAMP/PKA, just as the cAMP generation depends on the release of arachidonic acid, probably activating $\mathrm{EP}_{2 / 4^{-}}$or IP-receptors. These results were also proven in rat myometrial cells [71] and in GPs' airway SMCs [97]. Usually, stimuli which activate prostaglandin receptors coupling to $\mathrm{G}_{\alpha \mathrm{s}}$; e.g. $\mathrm{EP}_{2 / 4}$, IP or DP should increase intracellular cAMP $[98,99]$.

Aside from cAMP, NO seems to be of impact in PDGF-BB downstream-signalling. Though, NO-inhibition 
only slightly enhanced PDGF-BB-induced contraction (Fig. 8b). Our results are in line with those from Takase et al. [11] who perfused rat mesenteric arteries; there PDGF-BB stimulated NO-release even relaxed rat mesenteric arteries. The different characteristic of PDGF-BB-induced NO-release might be due to two facts; 1) Takase et al. [11] exposed rat mesenteric arteries to shear stress, generally going ahead with endothelial NO-release [100], 2) systemic and pulmonary vessel behave different to similar stimuli [70].

\section{PDGFR downstream-signalling: MAPK-pathway and PI3K- $a / Y$ and $A K T / P K B$}

With regard to cellular regulation (migration, differentiation, proliferation, growth or survival of cells), PDGFR downstream-signalling mainly activates two pathways: 1 ) the MAPK-pathway and 2) the PI3K/AKT/mTOR pathway [101]. Our data show that both inhibition of MAP2K by PD98059 or U-0126, as well as inhibition of p38-MAPK by SB 203580 almost prevented the contraction by PDGF-BB (Fig. 7a/b). Notably, GPs' PVs even relaxed slightly (Fig. 7a). In line with our data, Schaafsma et al. [102] showed in GPs tracheal strips that PDGF-BB-induced contraction highly depends on the activation of MAP2K. Next, Boulven et al. [71] proved in rat myometrial cells that PDGF-BB-dependent synthesis of prostaglandins is up to MAP2K. Conversely, the stimulating effect of PDGF-BB on phospholipase $\mathrm{A}_{2}\left(\mathrm{PLA}_{2}\right)$ and subsequent prostaglandin synthesis also depends on MAP2K [71, 103-105]. Finally, MAPK-signalling is highly involved in PDGF-BB-induced prostaglandin synthesis.

The PI3K/AKT/mTOR pathway highly contributes to mediate the proliferative aspects of PDGFR [3, 101]. Here both, PI3K- $\alpha$ which is expressed ubiquitously [106] and PI3K- $\gamma$ which is expressed in the cardiovascular system [106] contribute to the contractile effect of PDGF-BB. Hence, PI3K- $\gamma$ does not only regulate the systemic vascular tone [106], but is also of impact for the regulation of the pulmonary vascular tone. Together with the fact that inhibition of AKT/PKB (Fig. 7e) prevented the contractile effects in PVs, our results suggest a role of $\mathrm{PI} 3 \mathrm{~K} / \mathrm{AKT} / \mathrm{mTOR}$-signalling within the contractile effect of PDGF-BB. Our data are supported by Hua et al. [107] who showed that AKT prevents the degradation of cytosolic $\mathrm{PLA}_{2}\left(\mathrm{CPLA}_{2}\right)$, finally promoting prostaglandin synthesis. Beyond that, activation of AKT is linked to the activation of eNOS [108], an issue which seems to be negligible within PDGF-BB-induced regulation of the pulmonary venous tone, as 1) inhibition of AKT did not contract PVs and 2) as inhibition of eNOS enhanced the contractile effect of PDGF-BB only slightly (Fig. 8b). Further, our results are contrasting to those of Macrez et al. [109] who showed in vascular SMCs that the PDGF-BB-induced intracellular increase of calcium depends on PI3K- $\beta$, but not on PI3K- $\alpha$ which are both coupled to receptor tyrosine kinases (RTKs) [110-112]. Regarding PDGF-BB-signalling, non-direct activation of MAPK and PI3K is conceivable, as TP-receptors are also linked to $G_{\beta \gamma}$, finally leading to the activation of MAPKor PI3K/Akt/mTOR signalling [80].

In conclusion, prostaglandin generation appears to be a major mechanism beyond PDGF-BB-induced regulation of the pulmonary venous tone. Within this context, there are several possibilities to activate $\left.\mathrm{CPLA}_{2}, 1\right)$ by the increase of intracellular calcium [71, 104, 113], 2) by PDGF-BB-induced MAPK-signalling [71, 103-105] and 3 ) by the inhibitory properties of AKT on $\mathrm{CPLA}_{2}$-degradation [107]. In addition, 4) the transactivation of PDGFR by the $G_{\alpha q}$-coupled AngII is described [101], leading to the activation of PLC and $\mathrm{IP}_{3}$ and to the subsequent increase of intracellular calcium. For an overview, please see Fig. 10.

\section{The role of actin polymerisation in PDGF-BB-induced contraction}

Aside MLC-phosphorylation, actin polymerisation plays an important role within the contractile process of SMCs $[26,27]$. Within this context, it is of interest that PDGF-BB - via activation of SRC - stimulates the abelson tyrosine kinase (ABL) [114-116] which itself promotes actin polymerisation [27]. In contrast, the TKI imatinib is known to inhibit ABL [27].

Our data indicate that PDGF-BB-induced actin polymerisation contributes to the contractile effect of PDGF-BB, as inhibition of actin polymerisation by cytochalasin D (Fig. 9a) or latrunculin A (Fig. 9b) strongly reduced PDGF-BB-induced contraction in PVs. With regard to the stimulating effect of PDGF-BB on ABL, our results are comprehensible. They are even less unexpected, as MAPK-signalling which represents a cornerstone of PDGF-BB downstream signalling influences actin polymerisation [117, 118]. So far, the impact of actin polymerisation for the regulation of the pulmonary venous tone has not been shown. Although, its relevance for SMC-contraction was shown in SMCs of various vessel and species; e.g. canine carotids [119], ferret aorta [120], rat mesenteric arteries [121, 122], rat thoracic aorta [57] or rat extrapulmonary PAs [123], as well as in SMCs from airways [124].

\section{Link between PDGF-BB induced pulmonary vascular contraction and remodelling in $\mathrm{PH}$}

PDGFR-downstream-signalling is associated with the increase of intracellular calcium $[9,10,64]$. Here we show that the contractile effect of PDGF-BB also depends on it. Increased calcium-levels represent a major trigger for vasoconstriction, proliferation and migration of vascular SMCs [18, 80, 125-127]. Thus, stimuli which increase 


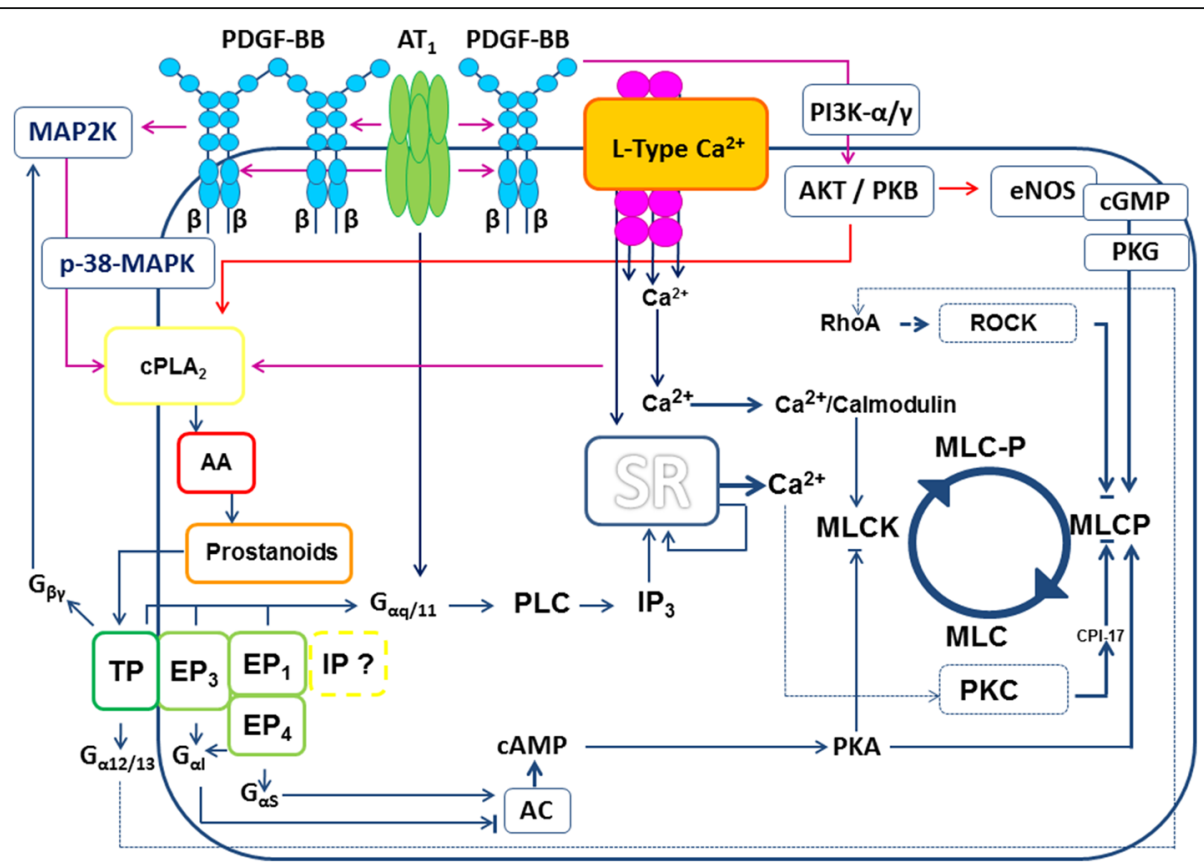

Fig. 10 Complex involvement of prostaglandins within the contractile effect of PDGF-BB. The contractile effect of PDGF-BB depends on the activation of $\mathrm{L}$-Type $\mathrm{Ca}^{2+}$-channels and on calcium $[9,10,64]$, promoting the activation of myosin light chain kinase (MLCK) and vascular SMC contraction [24]. Increased intracellular calcium-levels activate CPLA 2 [19] leading to the formation of arachidonic acid (AA) [131]. Cytosolic PLA 2 is also activated by MAP2K-/p-38-MAPK-signalling [71, 103], whereas PI3K- or AKT-signalling prevent its degradation [107]. AA serves as a substrate for the production of prostaglandins e.g. PGE $\mathrm{P}_{2}$ or $\mathrm{TXA}_{2}$ [132] which bind to EP- or TP-receptors. EP $1 / 3^{-}$or TP-receptors are mainly coupled to $\mathrm{G}_{\text {aq/ }}$ ${ }_{11}$, leading to the formation of $\mathrm{IP}_{3}$ and to the release of calcium from the sarcoplasmic reticulum (SR) $[25,88]$. TP-receptors are also linked to $\mathrm{G}_{\beta \gamma}$ activating MAPK-signalling [80]. Further, TP-receptors are coupled to $G_{a 12 / 13}[25,88]$ activating Rho/ROCK and inhibiting myosin light chain

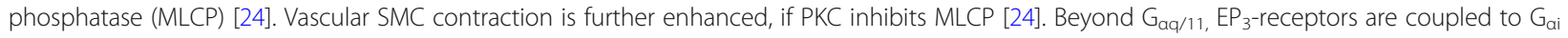
inhibiting CAMP-generation, whereas $\mathrm{EP}_{4}$-receptors are coupled to $\mathrm{G}_{\mathrm{as},}$, promoting CAMP-generation [25]. Cyclic AMP induces the formation of protein kinase A (PKA) which inhibits MLCK [23] and activates MLCP [133]. The role of PGI 2 and IP-receptor-activation is less relevant within PDGFR-downstream signalling, but is not completely solved. PDGFR-signalling also activates AKT/PKB [101] which stimulates eNOS [108]. Last, transactivation of $\mathrm{AT}_{1}$-receptors and PDGFR [101] is described leading to the increase of calcium [134]. The dashed line indicates pathways which are in contrast to our results

calcium-levels, e.g. TXA 2 or ET-1 [80, 128], but also hypoxia [125, 127] or PDGF-BB [2, 64] do not constrain to increase the pulmonary vascular tone, but also promote pulmonary vascular remodelling. Hence, enhanced tone and remodelling are closely linked with each other. In PH, this circumstance could be beneficial in view of new therapeutics, e.g. therapeutics addressing the mechanisms beyond PDGF-BB-induced contraction may attenuate vasoconstriction and remodelling. Ultimately, calcium-levels could be adressed directly by amlodipine or nifedipine, but also indirectly via inhibition of $\mathrm{TP} / \mathrm{EP}_{1 / 3}$ - receptors. In respect thereof it is worth mentioning that $\mathrm{EP}_{3}$-receptor deficiency attenuates $\mathrm{PH}$ [89] and that prednisolone inhibits PDGF-BB-induced proliferation of PAs' SMCs [129]. Further, inhibition of MAP2K-/AKT-signalling and $\mathrm{CPLA}_{2}$ could be of interest. Notably, the mentioned pathways could be addressed in a systemic way, but also topically, e.g. via inhalation to reduce systemic side effects.

\section{Conclusions}

PDGF-BB contracts pulmonary vessels. The PDGF-BB related pulmonary vascular effects are prevented by the TKI imatinib (perfused or nebulised). The mechanisms beyond PDGF-BB-induced contraction depend on actin polymerisation, the intracellular increase of calcium, activation of $\mathrm{EP}_{1 / 3 / 4^{-}}$and TP-receptors and MAP2K- or PI3K/AKT-signalling. In addition, PDGF-BB induces the release of $\mathrm{TXA}_{2}$ and cAMP. Finally, aside the known proliferative effects of PDGF-BB in PH, PDGF-BB-induced contraction might also contribute to the pathogenesis of $\mathrm{PH}$. Thus, TKI-inhibtion appears to be beneficial and particularly nebulised imatinib might prevent systemic side effect [130].

\section{Abbreviations}

6-keto PGF $_{1 a}$ : 6-keto prostaglandin $\mathrm{F}_{1 \mathrm{a}}$; AA: Arachidonic acid; $\mathrm{ABL}$ : Abelson tyrosine kinase; AC: Adenyl cyclase; Cdyn: Dynamic compliance; $\mathrm{CPLA}_{2}$ : Cytosolic phospholipase $\mathrm{A}_{2}$; eNOS: Endothelial NOS; EPreceptor: Prostaglandin $E_{2}$ receptor; GPCR: G-Protein-coupled receptor;

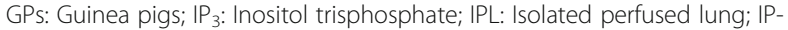
receptor: Prostacyclin receptor; IVA: Initial vessel area; LMM: Linear mixed 
model analysis; MLCK: Myosin light chain kinase; MLCP: Myosin light chain phosphatase; NOS: NO-synthase; PAs: Pulmonary arteries; $P_{\text {cap: }}$ Capillary pressure; PCLS: Precision-cut lung slices; PDGF: Platelet derived growth factor; PDGFR: PDGF-receptor; PGE 2 : Prostaglandin $E_{2} ;$ PGl 2 : Prostacyclin (prostaglandin $\mathrm{I}_{2}$ ); $\mathrm{PH}$ : Pulmonary hypertension; PKA: Protein kinase $\mathrm{A}_{\text {; }}$ PKC: Protein kinase C; PLA: Left atrial pressure; PLA2: Phospholipase $A_{2}$ PLC: Phospholipase C; PPA: Pulmonal arterial pressure; PVR: Pulmonary vascular resistance; PVs: Pulmonary veins; Res: Resistance; $R_{\text {post }}$ : Postcapillary pressure; Rpre: Precapillary pressure; RTK: Receptor tyrosine kinase; SMC: Smooth muscle cell; SR: Sarcoplasmic reticulum; TKIs: Tyrosine kinase inhibitors; TP-receptor: Thromboxane prostanoid receptor; TV: Tidal volume; $\mathrm{TXA}_{2}$ : Thromboxane $\mathrm{A}_{2} ; \mathrm{TXB}_{2}$ : 11-dehydro $\mathrm{TXB}_{2}$ and 2,3-dinor

\section{Acknowledgements}

This work was supported by the START programme of the RWTH-Aachen. We further gratefully acknowledge Hanna Czajkowska for excellent technical assistance.

\section{Funding}

This work was funded by the START programme (grant 109/14 (691440)) of the RWTH-Aachen. The funders had no influence of the study design, data collection and analysis, decision to publish or preparation of the manuscript.

\section{Availability of data and materials}

The datasets generated and analysed during the current study are available from the corresponding author on reasonable request.

\section{Authors' contributions}

ADR designed the study, performed the experiments, analysed the data, interpreted the data and wrote the manuscript. SS performed the experiments, analysed the data and interpreted the data. CA performed the experiments. EV performed the experiments, analysed the data and interpreted the data. RR analysed the data, interpreted the data and critically reviewed the manuscript. SU analysed the data, interpreted the data and critically reviewed the manuscript. CM designed the study, analysed the data, interpreted the data and critically reviewed the manuscript. All authors read and approved the final manuscript.

\section{Competing interest}

The authors declare that they have no competing interests.

\section{Ethics approval and consent to participate}

Female Dunkin Hartley GPs $(350 \pm 50 \mathrm{~g})$ were delivered from Charles River (Sulzfeld, Germany). All animal experiments were approved by the Landesamt für Natur, Umwelt und Verbraucherschutz Nordrhein-Westfalen (ID: 84-02.04.2013A146, 8.87-51.05.20.10.245 and 50066A4) and strictly performed according to the rules of the Directive 2010/63/EU of the European Parliament.

Intraperitoneal anaesthesia was performed (pentobarbital: $95 \mathrm{mg} \mathrm{kg}^{-1}$, Narcoren: Garbsen, Germany) and verified by missing reflexes, afterwards the animal was exsanguinated,

\section{Consent for publication}

Not applicable

\section{Publisher's Note}

Springer Nature remains neutral with regard to jurisdictional claims in published maps and institutional affiliations.

\section{Author details}

'Department of Anaesthesiology, Medical Faculty RWTH-Aachen, Aachen, Germany. ${ }^{2}$ Institute of Pharmacology and Toxicology, Medical Faculty RWTH-Aachen, Aachen, Germany.

\section{Received: 10 January 2018 Accepted: 13 June 2018}

\section{Published online: 19 June 2018}

\section{References}

1. Perros F, Montani D, Dorfmuller P, Durand-Gasselin I, Tcherakian C, Le PJ, Mazmanian M, Fadel E, Mussot S, Mercier O, Herve P, Emilie D, Eddahibi S, Simonneau G, Souza R, Humbert M. Platelet-derived growth factor expression and function in idiopathic pulmonary arterial hypertension. Am J Respir Crit Care Med. 2008;178:81-8. https://doi.org/10.1164/rccm.200707-10370C.

2. Schermuly RT, Dony E, Ghofrani HA, Pullamsetti S, Savai R, Roth M, Sydykov A, Lai YJ, Weissmann N, Seeger W, Grimminger F. Reversal of experimental pulmonary hypertension by PDGF inhibition. J Clin Invest. 2005;115:2811-21. https://doi.org/10.1172/JCI24838

3. Andrae J, Gallini R, Betsholtz C (2008) Role of platelet-derived growth factors in physiology and medicine. Genes Dev 22: 1276-1312. https://doi.org/10. 1101/gad.1653708 [doi].

4. Ten FH, Dumitrescu D, Berghausen E, Vantler M, Caglayan E, Rosenkranz S (2012) Imatinib mesylate for the treatment of pulmonary arterial hypertension. Expert Opin Investig Drugs 21: 119-134. https://doi.org/10. 1517/13543784.2012.632408 [doi].

5. Abe K, Toba M, Alzoubi A, Koubsky K, Ito M, Ota H, Gairhe S, Gerthoffer WT, Fagan KA, McMurtry IF, Oka M. Tyrosine kinase inhibitors are potent acute pulmonary vasodilators in rats. Am J Respir Cell Mol Biol. 2011;45:804-8. https://doi.org/10.1165/rcmb.2010-03710C.

6. Pankey EA, Thammasibon S, Lasker GF, Baber S, Lasky JA, Kadowitz PJ. Imatinib attenuates monocrotaline pulmonary hypertension and has potent vasodilator activity in the pulmonary and systemic vascular beds of the rat. Am J Physiol Heart Circ Physiol. 2013;305:1288-96. https://doi.org/10.1152/ ajpheart.00329.2013.

7. Maihofer NA, Suleiman S, Dreymuller D, Manley PW, Rossaint R, Uhlig S, Martin C, Rieg AD. Imatinib relaxes the pulmonary venous bed of guinea pigs. Respir Res. 2017;18:32. https://doi.org/10.1186/s12931-017-0514-0.

8. Maeda Y, Hirano K, Hirano M, Kikkawa Y, Kameda K, Sasaki T, Kanaide H. Enhanced contractile response of the basilar artery to platelet-derived growth factor in subarachnoid hemorrhage. Stroke. 2009;40:591-6. https:// doi.org/10.1161/STROKEAHA.108.530196.

9. Berk BC, Alexander RW, Brock TA, Gimbrone MA Jr, Webb RC. Vasoconstriction: a new activity for platelet-derived growth factor. Science. 1986;232:87-90.

10. Sachinidis A, Locher R, Hoppe J, Vetter W. The platelet-derived growth factor isomers, PDGF-AA, PDGF-AB and PDGF-BB, induce contraction of vascular smooth muscle cells by different intracellular mechanisms. FEBS Lett. 1990;275:95-8.

11. Takase H, Oemar BS, Pech M, Luscher TF. Platelet-derived growth factorinduced vasodilatation in mesenteric resistance arteries by nitric oxide: blunted response in spontaneous hypertension. J Cardiovasc Pharmacol. 1999;33:223-8.

12. Yamawaki H, Sato K, Hori M, Ozaki H, Karaki H. Platelet-derived growth factor causes endothelium-independent relaxation of rabbit mesenteric artery via the release of a prostanoid. Br J Pharmacol. 2000;131:1546-52. https://doi.org/10.1038/sj.bjp.0703771.

13. Rieg AD, Suleiman S, Perez-Bouza A, Braunschweig T, Spillner JW, Schroeder T, Verjans E, Schälte G, Rossaint R, Uhlig S, Martin C. Milrinone relaxes pulmonary veins in guinea pigs and humans. PLoS One. 2014;9(1):e87685.

14. Uhlig S, Wollin L. An improved setup for the isolated perfused rat lung. J Pharmacol Toxicol Methods. 1994;31:85-94.

15. Rieg AD, Rossaint R, Verjans E, Maihöfer NA, Uhlig S, Martin C. Levosimendan relaxes pulmonary arteries and veins in precision-cut lung slices - the role of KATP-channels, CAMP and CGMP. PLOS ONE. 2013;8(6): e66195. https://doi.org/10.1371/journal.pone.0066195.

16. Rieg AD, Rossaint $R$, Uhlig $S$, Martin $C$. Cardiovascular agents affect the tone of pulmonary arteries and veins in precision-cut lung slices. PLoS One. 2011; 6:e29698. https://doi.org/10.1371/journal.pone.0029698.

17. Barnes PJ, Liu SF. Regulation of pulmonary vascular tone. Pharmacol Rev. 1995;47:87-131.

18. Bonnet S, Archer SL. Potassium channel diversity in the pulmonary arteries and pulmonary veins: implications for regulation of the pulmonary vasculature in health and during pulmonary hypertension. Pharmacol Ther. 2007;115:56-69. https://doi.org/10.1016/j.pharmthera.2007.03.014.

19. Feletou M, Huang $Y$, Vanhoutte PM. Vasoconstrictor prostanoids. Pflugers Arch. 2010;459:941-50. https://doi.org/10.1007/s00424-010-0812-6.

20. Khalil RA. Regulation of Vascular Smooth Muscle Function. San Rafael (CA) Integrated Systems Physiology: From Molecule to Function. Morgan \& Claypool Life Sciences; 2010.

21. Ko EA, Han J, Jung ID, Park WS. Physiological roles of K+ channels in vascular smooth muscle cells. J Smooth Muscle Res. 2008;44:65-81.

22. Morello F, Perino A, Hirsch E. Phosphoinositide 3-kinase signalling in the vascular system. Cardiovasc Res. 2009;82:261-71. https://doi.org/10.1093/cvr/ cvn325. 
23. Morgado M, Cairrao E, Santos-Silva AJ, Verde I. Cyclic nucleotide-dependent relaxation pathways in vascular smooth muscle. Cell Mol Life Sci. 2012;69: 247-66.

24. Puetz S, Lubomirov LT, Pfitzer G. Regulation of smooth muscle contraction by small GTPases. Physiology (Bethesda). 2009;24:342-56. https://doi.org/10. 1152/physiol.00023.2009.

25. Sugimoto Y, Narumiya S. Prostaglandin E receptors. J Biol Chem. 2007;282: 11613-7. https://doi.org/10.1074/jbc.R600038200.

26. Gunst SJ, Zhang W. Actin cytoskeletal dynamics in smooth muscle: a new paradigm for the regulation of smooth muscle contraction. Am J Physiol Cell Physiol. 2008;295:C576-87. https://doi.org/10.1152/ajpcell.00253.2008.

27. Tang DD. Critical role of actin-associated proteins in smooth muscle contraction, cell proliferation, airway hyperresponsiveness and aimay remodeling. Respir Res. 2015;16:134. https://doi.org/10.1186/s12931-015-0296-1.

28. Schleputz M, Rieg AD, Seehase S, Spillner J, Perez-Bouza A, Braunschweig T, Schroeder T, Bernau M, Lambermont V, Schlumbohm C, Sewald K, Autschbach R, Braun A, Kramer BW, Uhlig S, Martin C. Neurally mediated airway constriction in human and other species: a comparative study using precision-cut lung slices (PCLS). PLoS One. 2012;7:e47344. https://doi.org/10. 1371/journal.pone.0047344.

29. Held HD, Martin C, Uhlig S. Characterization of airway and vascular responses in murine lungs. Br J Pharmacol. 1999;126:1191-9. https://doi.org/ 10.1038/sj.bjp.0702394.

30. Ressmeyer A, Larsson A, Vollmer E, Dahlen S, Uhlig S, Martin C. Characterisation of guinea pig precision-cut lung slices: comparison with human tissues. Eur Respir J. 2006;28:603-11.

31. Atzori L, Bannenberg G, Corriga AM, Moldeus P, Ryrfeldt A. Sulfur dioxideinduced bronchoconstriction in the isolated perfused and ventilated guinea-pig lung. Respiration. 1992;59:16-21.

32. Sachs H. Elektronik Harvard Apparatus GmbH, inventor; Operating Instructions for PARI Jet-Nebulizer No. 73-1963. 2008

33. Gozgit JM, Wong MJ, Wardwell S, Tyner JW, Loriaux MM, Mohemmad QK, Narasimhan NI, Shakespeare WC, Wang F, Druker BJ, Clackson T, Rivera VM Potent activity of ponatinib (AP24534) in models of FLT3-driven acute myeloid leukemia and other hematologic malignancies. Mol Cancer Ther. 2011;10:1028-35. https://doi.org/10.1158/1535-7163.MCT-10-1044.

34. Huang WS, Metcalf CA, Sundaramoorthi R, Wang Y, Zou D, Thomas RM, Zhu X, Cai L, Wen D, Liu S, Romero J, Qi J, Chen I, Banda G, Lentini SP, Das S, Xu Q, Keats J, Wang F, Wardwell S, Ning Y, Snodgrass JT, Broudy MI, Russian K, Zhou T, Commodore L, Narasimhan NI, Mohemmad QK, luliucci J, Rivera VM, Dalgarno DC, Sawyer TK, Clackson T, Shakespeare WC. Discovery of 3[2-(imidazo[1,2-b]pyridazin-3-yl)ethynyl]-4-methyl-N-\{4-[(4-methylpiperazin-1y l)methyl]-3-(trifluoromethyl)phenyl\}benzamide (AP24534), a potent, orally active pan-inhibitor of breakpoint cluster region-abelson (BCR-ABL) kinase including the T315I gatekeeper mutant. J Med Chem. 2010;53:4701-19. https://doi.org/10.1021/jm100395q.

35. O'Hare T, Shakespeare WC, Zhu X, Eide CA, Rivera VM, Wang F, Adrian LT, Zhou T, Huang WS, Xu Q, Metcalf CA III, Tyner JW, Loriaux MM, Corbin AS, Wardwell S, Ning Y, Keats JA, Wang Y, Sundaramoorthi R, Thomas M, Zhou D, Snodgrass J, Commodore L, Sawyer TK, Dalgarno DC, Deininger MW, Druker BJ, Clackson T. AP24534, a pan-BCR-ABL inhibitor for chronic myeloid leukemia, potently inhibits the T315I mutant and overcomes mutation-based resistance. Cancer Cell. 2009;16:401-12. https://doi.org/10.1016/j.ccr.2009.09.028.

36. Godl K, Gruss OJ, Eickhoff J, Wissing J, Blencke S, Weber M, Degen H, Brehmer D, Orfi L, Horvath Z, Keri G, Muller S, Cotten M, Ullrich A, Daub H. Proteomic characterization of the angiogenesis inhibitor SU6668 reveals multiple impacts on cellular kinase signaling. Cancer Res. 2005;65:6919-26. https://doi.org/10.1158/0008-5472.CAN-05-0574.

37. Laird AD, Vajkoczy $P$, Shawver LK, Thurnher A, Liang C, Mohammadi M, Schlessinger J, Ullrich A, Hubbard SR, Blake RA, Fong TA, Strawn LM, Sun L, Tang C, Hawtin R, Tang F, Shenoy N, Hirth KP, McMahon G, Cherrington. SU6668 is a potent antiangiogenic and antitumor agent that induces regression of established tumors. Cancer Res. 2000;60:4152-60.

38. Laird AD, Christensen JG, Li G, Carver J, Smith K, Xin X, Moss KG, Louie SG, Mendel DB, Cherrington JM. SU6668 inhibits Flk-1/KDR and PDGFRbeta in vivo, resulting in rapid apoptosis of tumor vasculature and tumor regression in mice. FASEB J. 2002;16:681-90. https://doi.org/10.1096/fj.01-0700com.

39. Medarametla V, Festin S, Sugarragchaa C, Eng A, Naqwi A, Wiedmann T, Zisman LS. PK10453, a nonselective platelet-derived growth factor receptor inhibitor, prevents the progression of pulmonary arterial hypertension. Pulm Circ. 2014;4:82-102. https://doi.org/10.1086/674881.
40. Burges RA, Gardiner DG, Gwilt M, Higgins AJ, Blackburn KJ, Campbell SF, Cross PE, Stubbs JK. Calcium channel blocking properties of amlodipine in vascular smooth muscle and cardiac muscle in vitro: evidence for voltage modulation of vascular dihydropyridine receptors. J Cardiovasc Pharmacol. 1987:9:110-9.

41. Pfitzer G, Sonntag-Bensch D, Brkic-Koric D. Thiophosphorylation-induced $\mathrm{ca}(2+)$ sensitization of guinea-pig ileum contractility is not mediated by rhoassociated kinase. J Physiol. 2001;533:651-64.

42. Pollack IF, Kawecki S. The effect of calphostin C, a potent photodependent protein kinase $C$ inhibitor, on the proliferation of glioma cells in vitro. J Neuro-Oncol. 1997;31:255-66.

43. Range SP, Pang L, Holland E, Knox AJ. Selectivity of cyclo-oxygenase inhibitors in human pulmonary epithelial and smooth muscle cells. Eur Respir J. 2000;15:751-6.

44. Riendeau D, Percival MD, Boyce S, Brideau C, Charleson S, Cromlish W, Ethier D, Evans J, Falgueyret JP, Ford-Hutchinson AW, Gordon R, Greig G, Gresser M, Guay J, Kargman S, Leger S, Mancini JA, O'Neill G, Ouellet M, Rodger IW, Therien M, Wang Z, Webb JK, Wong E, Chan CC. Biochemical and pharmacological profile of a tetrasubstituted furanone as a highly selective COX-2 inhibitor. Br J Pharmacol. 1997;121:105-17. https://doi.org/ 10.1038/sj.bjp.0701076.

45. Durocher Y, Perret S, Thibaudeau E, Gaumond MH, Kamen A, Stocco R, Abramovitz M. A reporter gene assay for high-throughput screening of $\mathrm{G}$ protein-coupled receptors stably or transiently expressed in HEK293 EBNA cells grown in suspension culture. Anal Biochem. 2000;284:316-26. https:// doi.org/10.1006/abio.2000.4698.

46. Af Forselles K, Root J, Clarke T, Davey D, Aughton K, Dack K, Pullen N. In vitro and in vivo characterization of PF-04418948, a novel, potent and selective prostaglandin EP(2) receptor antagonist. Br J Pharmacol. 2011;164: 1847-56. https://doi.org/10.1111/j.1476-5381.2011.01495.x.

47. Birrell MA, Maher SA, Buckley J, Dale N, Bonvini S, Raemdonck K, Pullen N, Giembycz MA, Belvisi MG. Selectivity profiling of the novel EP2 receptor antagonist, PF-04418948, in functional bioassay systems: atypical affinity at the guinea pig EP2 receptor. Br J Pharmacol. 2013;168:129-38. https://doi. org/10.1111/j.1476-5381.2012.02088.x.

48. Jones RL, Giembycz MA, Woodward DF. Prostanoid receptor antagonists: development strategies and therapeutic applications. Br J Pharmacol. 2009; 158:104-45. https://doi.org/10.1111/j.1476-5381.2009.00317.x.

49. Juteau H, Gareau Y, Labelle M, Sturino CF, Sawyer N, Tremblay N, Lamontagne S, Carriere MC, Denis D, Metters KM. Structure-activity relationship of cinnamic acylsulfonamide analogues on the human EP3 prostanoid receptor. Bioorg Med Chem. 2001;9:1977-84.

50. Jones RL, Wise H, Clark R, Whiting RL, Bley KR. Investigation of the prostacyclin (IP) receptor antagonist RO1138452 on isolated blood vessel and platelet preparations. Br J Pharmacol. 2006;149:110-20. https://doi.org/ 10.1038/sj.bjp.0706841

51. Alessi DR, Cuenda A, Cohen P, Dudley DT, Saltiel AR. PD 098059 is a specific inhibitor of the activation of mitogen-activated protein kinase kinase in vitro and in vivo. J Biol Chem. 1995;270:27489-94.

52. Favata MF, Horiuchi KY, Manos EJ, Daulerio AJ, Stradley DA, Feeser WS, Van Dyk DE, Pitts WJ, Earl RA, Hobbs F, Copeland RA, Magolda RL, Scherle PA, Trzaskos JM. Identification of a novel inhibitor of mitogen-activated protein kinase kinase. J Biol Chem. 1998;273:18623-32.

53. Cuenda A, Rouse J, Doza YN, Meier R, Cohen P, Gallagher TF, Young PR, Lee JC. SB 203580 is a specific inhibitor of a MAP kinase homologue which is stimulated by cellular stresses and interleukin-1. FEBS Lett. 1995;364:229-33.

54. Lali FV, Hunt AE, Turner SJ, Foxwell BM. The pyridinyl imidazole inhibitor SB203580 blocks phosphoinositide-dependent protein kinase activity, protein kinase B phosphorylation, and retinoblastoma hyperphosphorylation in interleukin-2-stimulated T cells independently of p38 mitogen-activated protein kinase. J Biol Chem. 2000;275:7395-402.

55. Pomel V, Klicic J, Covini D, Church DD, Shaw JP, Roulin K, Burgat-Charvillon F, Valognes D, Camps M, Chabert C, Gillieron C, Francon B, Perrin D, Leroy D, Gretener D, Nichols A, Vitte PA, Carboni S, Rommel C, Schwarz MK, Ruckle T. Furan-2-ylmethylene thiazolidinediones as novel, potent, and selective inhibitors of phosphoinositide 3-kinase gamma. J Med Chem. 2006;49:3857-71. https://doi.org/10.1021/jm0601598.

56. Thimmaiah KN, Easton JB, Germain GS, Morton CL, Kamath S, Buolamwini JK, Houghton PJ. Identification of N10-substituted phenoxazines as potent and specific inhibitors of Akt signaling. J Biol Chem. 2005;280:31924-35. https://doi. org/10.1074/jbc.M507057200. 
57. Saito SY, Hori M, Ozaki H, Karaki H. Cytochalasin D inhibits smooth muscle contraction by directly inhibiting contractile apparatus. J Smooth Muscle Res. 1996:32:51-60.

58. Coue M, Brenner SL, Spector I, Korn ED. Inhibition of actin polymerization by latrunculin a. FEBS Lett. 1987;213:316-8

59. Hourani SM, Boon K, Fooks HM, Prentice DJ. Role of cyclic nucleotides in vasodilations of the rat thoracic aorta induced by adenosine analogues. $\mathrm{Br} J$ Pharmacol. 2001;133:833-40.

60. Gao Y, Raj JU. Role of veins in regulation of pulmonary circulation. Am J Physiol Lung Cell Mol Physiol. 2005;288:L213-26. https://doi.org/10.1152/ ajplung.00103.2004.

61. McLaughlin W, Archer SL, Badesch DB, Barst RJ, Farber HW, Lindner JR, Mathier MA, McGoon MD, Park MH, Rosenson RS, Rubin LJ, Tapson VF, Varga J. ACCF/ AHA 2009 expert consensus document on pulmonary hypertension a report of the American College of Cardiology Foundation task force on expert consensus documents and the American Heart Association developed in collaboration with the American College of Chest Physicians; American Thoracic Society, Inc.; and the Pulmonary Hypertension Association. J Am Coll Cardiol. 2009:53:1573-619. https://doi.org/10.1016/j.jacc.2009.01.004

62. Adir Y, Offer A. Pulmonary hypertension associated with left heart disease. Eur Respir Monogr. 2012:57:119-37.

63. Guazzi M, Galie N. Pulmonary hypertension in left heart disease. Eur Respir Rev. 2012;21:338-46. https://doi.org/10.1183/09059180.00004612.

64. Hughes AD. Increase in tone and intracellular $\mathrm{Ca} 2+$ in rabbit isolated ear artery by platelet-derived growth factor. Br J Pharmacol. 1995;114:138-42.

65. Hoeper MM, Barst RJ, Bourge RC, Feldman J, Frost AE, Galie N, GomezSanchez MA, Grimminger F, Grunig E, Hassoun PM, Morrell NW, Peacock AJ, Satoh T, Simonneau G, Tapson VF, Torres F, Lawrence D, Quinn DA, Ghofrani HA. Imatinib mesylate as add-on therapy for pulmonary arterial hypertension: results of the randomized IMPRES study. Circulation. 2013;127: 1128-38. https://doi.org/10.1161/CIRCULATIONAHA.112.000765.

66. Block LH, Emmons LR, Vogt E, Sachinidis A, Vetter W, Hoppe J. Ca2+-channe blockers inhibit the action of recombinant platelet-derived growth factor in vascular smooth muscle cells. Proc Natl Acad Sci U S A. 1989:86:2388-92

67. Liu H, Li K, Sperelakis N. Tyrosine kinase inhibitor, genistein, inhibits macroscopic L-type calcium current in rat portal vein smooth muscle cells. Can J Physiol Pharmacol. 1997;75:1058-62.

68. Liu H, Sperelakis $\mathrm{N}$. Tyrosine kinases modulate the activity of single L-type calcium channels in vascular smooth muscle cells from rat portal vein. Can J Physiol Pharmacol. 1997;75:1063-8.

69. Sachinidis A, Locher R, Vetter W, Tatje D, Hoppe J. Different effects of platelet-derived growth factor isoforms on rat vascular smooth muscle cells. J Biol Chem. 1990;265:10238-43.

70. Kuebler WM, Yang Y, Samapati R, Uhlig S. Vascular barrier regulation by PAF, ceramide, caveolae, and NO - an intricate signaling network with discrepant effects in the pulmonary and systemic vasculature. Cell Physiol Biochem. 2010;26:29-40. https://doi.org/10.1159/000315103.

71. Boulven I, Palmier B, Robin P, Vacher M, Harbon S, Leiber D. Platelet-derived growth factor stimulates phospholipase C-gamma 1, extracellular signalregulated kinase, and arachidonic acid release in rat myometrial cells: contribution to cyclic 3',5'-adenosine monophosphate production and effect on cell proliferation. Biol Reprod. 2001;65:496-506.

72. Lopez-Rivas A, Stroobant P, Waterfield MD, Rozengurt E. lonic responses rapidly elicited by porcine platelet-derived growth factor in Swiss $3 \mathrm{~T} 3$ cells. EMBO J. 1984;3:939-44

73. Wu E, Palmer N, Tian Z, Moseman AP, Galdzicki M, Wang X, Berger B, Zhang $\mathrm{H}$, Kohane IS. Comprehensive dissection of PDGF-PDGFR signaling pathways in PDGFR genetically defined cells. PLoS One. 2008;3:e3794. https://doi.org/ 10.1371/journal.pone.0003794.

74. Qian YM, Jones RL, Chan KM, Stock Al, Ho JK. Potent contractile actions of prostanoid EP3-receptor agonists on human isolated pulmonary artery. Br J Pharmacol. 1994:113:369-74.

75. Norel X, Walch L, Gascard JP, deMontpreville V, Brink C. Prostacyclin release and receptor activation: differential control of human pulmonary venous and arterial tone. Br J Pharmacol. 2004;142:788-96. https://doi. org/10.1038/sj.bjp.0705843.

76. Walch L, de M, V, Brink C, Norel X (2001) Prostanoid EP(1)- and TP-receptors involved in the contraction of human pulmonary veins. Br J Pharmacol 134: 1671-1678. https://doi.org/10.1038/sj.bjp.0704423 [doi].

77. Montani D, Chaumais MC, Guignabert C, Gunther S, Girerd B, Jais X, Algalarrondo V, Price LC, Savale L, Sitbon O, Simonneau G, Humbert M.
Targeted therapies in pulmonary arterial hypertension. Pharmacol Ther. 2014;141:172-91. https://doi.org/10.1016/j.pharmthera.2013.10.002.

78. Ogletree ML. Overview of physiological and pathophysiological effects of thromboxane A2. Fed Proc. 1987;46:133-8.

79. Pluchart H, Khouri C, Blaise S, Roustit M, Cracowski JL (2017) Targeting the Prostacyclin Pathway: Beyond Pulmonary Arterial Hypertension. Trends Pharmacol Sci S0165-6147(17)30048-2;https://doi.org/10.1016/j.tips2017.03.003.

80. Nakahata N. Thromboxane A2: physiology/pathophysiology, cellular signal transduction and pharmacology. Pharmacol Ther. 2008;118:18-35. https:// doi.org/10.1016/j.pharmthera.2008.01.001.

81. Carrithers JA, Brown D, Liu F, Orr JA. Thromboxane A2 mimetic U-46619 induces systemic and pulmonary hypertension and delayed tachypnea in the goat. J Appl Physiol. 1985;77:1466-73.

82. Liu C, Tazzeo T, Lippton H, Janssen LJ. Role of tyrosine phosphorylation in U46619-induced vasoconstriction of pulmonary vasculature and its modulation by genistein, daidzein, and equol. J Cardiovasc Pharmacol. 2007; 50:441-8. https://doi.org/10.1097/FJC.0b013e31813542bd.

83. Liu F, Wu JY, Beasley D, Orr JA. TxA2-induced pulmonary artery contraction requires extracellular calcium. Respir Physiol. 1997;109:155-66.

84. Murtha YM, Allen BM, Orr JA. The role of protein kinase $C$ in thromboxane A2-induced pulmonary artery vasoconstriction. J Biomed Sci. 1999;6:293-5. 25398 [doi]

85. Huang JS, Ramamurthy SK, Lin X, Le Breton GC (2004) Cell signalling through thromboxane A2 receptors. Cell Signal 16: 521-533.

86. Filep JG, Fournier A, Foldes-Filep E. Endothelin-1-induced myocardial ischaemia and oedema in the rat: involvement of the ETA receptor, platelet-activating factor and thromboxane A2. Br J Pharmacol. 1994; 112:963-71.

87. Takayasu-Okishio M, Terashita Z, Kondo K. Endothelin-1 and platelet activating factor stimulate thromboxane $\mathrm{A} 2$ biosynthesis in rat vascular smooth muscle cells. Biochem Pharmacol. 1990;40:2713-7.

88. Markovic T, Jakopin Z, Dolenc MS, Mlinaric-Rascan I (2017) Structural features of subtype-selective EP receptor modulators. Drug Discov Today 22: 57-71. S1359-https://doi.org/10.1016/j.drudis.2016.08.003 [doi].

89. Lu A, Zuo C, He Y, Chen G, Piao L, Zhang J, Xiao B, Shen Y, Tang J, Kong D, Alberti S, Chen D, Zuo S, Zhang Q, Yan S, Fei X, Yuan F, Zhou B, Duan S, Yu Y, Lazarus M, Su Y, Breyer RM, Funk CD, Yu Y. EP3 receptor deficiency attenuates pulmonary hypertension through suppression of Rho/TGF-beta1 signaling. J Clin Invest. 2015;125:1228-42. https://doi.org/10.1172/JCI77656.

90. Yan G, Wang Q, Shi H, Han Y, Ma G, Tang C, Gu Y. Regulation of rat intrapulmonary arterial tone by arachidonic acid and prostaglandin E2 during hypoxia. PLoS One. 2013;8:e73839. https:/doi.org/10.1371/journal.pone.0073839.

91. Lang IM, Gaine SP (2015) Recent advances in targeting the prostacyclin pathway in pulmonary arterial hypertension. Eur Respir Rev 24: 630-641. https://doi.org/10.1183/16000617.0067-2015 [doi].

92. Okahara K, Sun B, Kambayashi J. Upregulation of prostacyclin synthesisrelated gene expression by shear stress in vascular endothelial cells. Arterioscler Thromb Vasc Biol. 1998;18:1922-6.

93. Russell-Puleri S, Dela Paz NG, Adams D, Chattopadhyay M, Cancel L, Ebong E, Orr AW, Frangos JA, Tarbell JM. Fluid shear stress induces upregulation of COX-2 and PGI2 release in endothelial cells via a pathway involving PECAM1, PI3K, FAK, and p38. Am J Physiol Heart Circ Physiol. 2017;312:H485-500. https://doi.org/10.1152/ajpheart.00035.2016.

94. Alshihabi SN, Chang YS, Frangos JA, Tarbell JM. Shear stress-induced release of PGE2 and PGI2 by vascular smooth muscle cells. Biochem Biophys Res Commun. 1996;224:808-14. https://doi.org/10.1006/bbrc.1996.1104.

95. Paddenberg R, Mermer P, Goldenberg A, Kummer W (2014) Videomorphometric analysis of hypoxic pulmonary vasoconstriction of intrapulmonary arteries using murine precision cut lung slices. J Vis Exp e50970. https://doi.org/10.3791/50970 [doi].

96. Graves LM, Bornfeldt KE, Sidhu JS, Argast GM, Raines EW, Ross R, Leslie CC, Krebs EG. Platelet-derived growth factor stimulates protein kinase a through a mitogen-activated protein kinase-dependent pathway in human arterial smooth muscle cells. J Biol Chem. 1996:271:505-11.

97. Pyne NJ, Pyne S. PDGF-stimulated cyclic AMP formation in airway smooth muscle: assessment of the roles of MAP kinase, cytosolic phospholipase A2, and arachidonate metabolites. Cell Signal. 1998;10:363-9.

98. Matsuoka T, Narumiya S. Prostaglandin receptor signaling in disease. ScientificWorld J. 2007;7:1329-47. https://doi.org/10.1100/tsw.2007.182.

99. Yuhki K, Kojima F, Kashiwagi H, Kawabe J, Fujino T, Narumiya S, Ushikubi F. Roles of prostanoids in the pathogenesis of cardiovascular diseases: novel 
insights from knockout mouse studies. Pharmacol Ther. 2011;129:195-205. https://doi.org/10.1016/j.pharmthera.2010.09.004.

100. Xu S, Li X, LaPenna KB, Yokota SD, Huke S, He P. New insights into shear stress-induced endothelial signalling and barrier function: cell-free fluid versus blood flow. Cardiovasc Res. 2017;113:508-18. https://doi.org/10.1093/ $\mathrm{CVr} / \mathrm{cr} \times 021$.

101. Noskovicova N, Petrek M, Eickelberg O, Heinzelmann K. Platelet-derived growth factor signaling in the lung. From lung development and disease to clinical studies. Am J Respir Cell Mol Biol. 2015;52:263-84. https://doi.org/10. 1165/rcmb.2014-0294TR.

102. Schaafsma D, Gosens R, Bos IS, Meurs H, Zaagsma J, Nelemans SA (2005) Role of contractile prostaglandins and rho-kinase in growth factor-induced airway smooth muscle contraction. Respir Res 6: 85. https://doi.org/10.1186/ 1465-9921-6-85 [doi].

103. Bornfeldt KE, Campbell JS, Koyama H, Argast GM, Leslie CC, Raines EW, Krebs EG, Ross R. The mitogen-activated protein kinase pathway can mediate growth inhibition and proliferation in smooth muscle cells. Dependence on the availability of downstream targets. J Clin Invest. 1997; 100:875-85. https://doi.org/10.1172/JCl119603.

104. Gijon MA, Leslie CC. Regulation of arachidonic acid release and cytosolic phospholipase A2 activation. J Leukoc Biol. 1999;65:330-6.

105. Karpova AY, Abe MK, Li J, Liu PT, Rhee JM, Kuo WL, Hershenson MB. MEK1 is required for PDGF-induced ERK activation and DNA synthesis in tracheal myocytes. Am J Phys. 1997;272:L558-65.

106. Carnevale D, Lembo G. PI3Kgamma in hypertension: a novel therapeutic target controlling vascular myogenic tone and target organ damage. Cardiovasc Res. 2012;95:403-8. https://doi.org/10.1093/cvr/cvs166.

107. Hua S, Vignarajan S, Yao M, Xie C, Sved P, Dong Q. AKT and cytosolic phospholipase A2alpha form a positive loop in prostate cancer cells. Curr Cancer Drug Targets. 2015;15:781-91.

108. Abeyrathna P, Su Y. The critical role of Akt in cardiovascular function. Vasc Pharmacol. 2015;74:38-48. https://doi.org/10.1016/j.vph.2015.05.008.

109. Macrez N, Mironneau C, Carricaburu V, Quignard JF, Babich A, Czupalla C, Nurnberg B, Mironneau J. Phosphoinositide 3-kinase isoforms selectively couple receptors to vascular L-type ca(2+) channels. Circ Res. 2001;89:692-9.

110. Crabbe T, Welham MJ, Ward SG. The PI3K inhibitor arsenal: choose your weapon! Trends Biochem Sci. 2007;32:450-6. https://doi.org/10.1016/j.tibs. 2007.09.001

111. Kong D, Yamori T. Phosphatidylinositol 3-kinase inhibitors: promising drug candidates for cancer therapy. Cancer Sci. 2008;99:1734-40. https://doi.org/ 10.1111/j.1349-7006.2008.00891.x

112. Sasaki T, Irie-Sasaki J, Jones RG, Oliveira-dos-Santos AJ, Stanford WL, Bolon B, Wakeham A, Itie A, Bouchard D, Kozieradzki I, Joza N, Mak TW, Ohashi PS, Suzuki A, Penninger JM. Function of PI3Kgamma in thymocyte development, T cell activation, and neutrophil migration. Science. 2000;287: 1040-6.

113. Leslie CC. Properties and regulation of cytosolic phospholipase A2. J Biol Chem. 1997;272:16709-12.

114. Beazely MA, Weerapura M, MacDonald JF. Abelson tyrosine kinase links PDGFbeta receptor activation to cytoskeletal regulation of NMDA receptors in CA1 hippocampal neurons. Mol Brain. 2008;1:20. https://doi.org/10.1186/ 1756-6606-1-20.

115. Hantschel O, Superti-Furga G. Regulation of the c-Abl and Bcr-Abl tyrosine kinases. Nat Rev Mol Cell Biol. 2004;5:33-44. https://doi.org/10.1038/ nrm1280.

116. Jia $L$, Wang $R$, Tang DD. Abl regulates smooth muscle cell proliferation by modulating actin dynamics and ERK1/2 activation. Am J Physiol Cell Physiol. 2012;302:C1026-34. https://doi.org/10.1152/ajpcell.00373.2011.

117. Sasahara T, Yayama K, Okamoto H. p38 mitogen-activated protein kinase mediates hyperosmolarity-induced vasoconstriction through myosin light chain phosphorylation and actin polymerization in rat aorta. Biol Pharm Bull. 2013;36:1849-56

118. Tang DD, Anfinogenova Y. Physiologic properties and regulation of the actin cytoskeleton in vascular smooth muscle. J Cardiovasc Pharmacol Ther. 2008;13:130-40. https://doi.org/10.1177/1074248407313737.

119. Tang DD, Tan J. Downregulation of profilin with antisense oligodeoxynucleotides inhibits force development during stimulation of smooth muscle. Am J Physiol Heart Circ Physiol. 2003;285:H1528-36. https:// doi.org/10.1152/ajpheart.00188.2003.

120. Kim HR, Graceffa P, Ferron F, Gallant C, Boczkowska M, Dominguez R, Morgan KG. Actin polymerization in differentiated vascular smooth muscle cells requires vasodilator-stimulated phosphoprotein. Am J Physiol Cell Physiol. 2010;298:C559-71. https://doi.org/10.1152/ajpcell.00431.2009.

121. Chen X, Pavlish K, Zhang HY, Benoit JN. Effects of chronic portal hypertension on agonist-induced actin polymerization in small mesenteric arteries. Am J Physiol Heart Circ Physiol. 2006;290:H1915-21. https://doi.org/ 10.1152/ajpheart.00643.2005

122. Ohanian V, Gatfield K, Ohanian J. Role of the actin cytoskeleton in Gprotein-coupled receptor activation of PYK2 and paxillin in vascular smooth muscle. Hypertension. 2005;46:93-9. https://doi.org/10.1161/01.HYP. 0000167990.82235.3c.

123. Adler KB, Krill J, Alberghini TV, Evans JN. Effect of cytochalasin D on smooth muscle contraction. Cell Motil. 1983;3:545-51.

124. Cleary RA, Wang R, Wang T, Tang DD. Role of Abl in airway hyperresponsiveness and airway remodeling. Respir Res. 2013;14:105. https://doi.org/10.1186/1465-9921-14-105.

125. Jernigan NL. Smooth muscle acid-sensing ion channel 1: pathophysiological implication in hypoxic pulmonary hypertension. Exp Physiol. 2015;100:11120. https://doi.org/10.1113/expphysiol.2014.081612.

126. Revermann M, Schloss M, Mieth A, Babelova A, Schroder K, Neofitidou S, Buerkl J, Kirschning T, Schermuly RT, Hofstetter C, Brandes RP. Levosimendan attenuates pulmonary vascular remodeling. Intensive Care Med. 2011:37:1368-77.

127. Wang $Q$, Wang $D$, Yan $G$, Sun $L$, Tang C. TRPC6 is required for hypoxiainduced basal intracellular calcium concentration elevation, and for the proliferation and migration of rat distal pulmonary venous smooth muscle cells. Mol Med Rep. 2016;13:1577-85.

128. Deacon K, Knox AJ. Endothelin-1 (ET-1) increases the expression of remodeling genes in vascular smooth muscle through linked calcium and cAMP pathways: role of a phospholipase a(2)(CPLA(2))/cyclooxygenase-2 (COX-2)/prostacyclin receptor-dependent autocrine loop. J Biol Chem. 2010; 285:25913-27. https://doi.org/10.1074/jbc.M110.139485.

129. Ogawa A, Nakamura K, Matsubara H, Fujio H, Ikeda T, Kobayashi K, Miyazaki I, Asanuma M, Miyaji K, Miura D, Kusano KF, Date H, Ohe T. Prednisolone inhibits proliferation of cultured pulmonary artery smooth muscle cells of patients with idiopathic pulmonary arterial hypertension. Circulation. 2005: 112:1806-12. https://doi.org/10.1161/CIRCULATIONAHA.105.536169.

130. Frost AE, Barst RJ, Hoeper MM, Chang HJ, Frantz RP, Fukumoto Y, Galie N, Hassoun PM, Klose H, Matsubara H, Morrell NW, Peacock AJ, Pfeifer M, Simonneau G, Tapson VF, Torres F, Dario VC, Lawrence D, Yang W, Felser JM, Quinn DA, Ghofrani HA. Long-term safety and efficacy of imatinib in pulmonary arterial hypertension. J Heart Lung Transplant. 2015;34:1366-75. https://doi.org/10.1016/j.healun.2015.05.025

131. Dennis EA. Diversity of group types, regulation, and function of phospholipase A2. J Biol Chem. 1994:269:13057-60.

132. Gryglewski RJ. Prostacyclin among prostanoids. Pharmacol Rep. 2008;60:311.

133. Lubomirov LT, Schubert R, Gagov HS, Duridanova DB, Pfitzer G. Urocortin decreases phosphorylation of MYPT1 and increases the myosin phosphatase activity via elevation of the intracellular level of cAMP. Biofizika. 2006;51: $773-80$

134. Mehta PK, Griendling KK. Angiotensin II cell signaling: physiological and pathological effects in the cardiovascular system. Am J Physiol Cell Physiol. 2007;292:C82-97. https://doi.org/10.1152/ajpcell.00287.2006.

\section{Ready to submit your research? Choose BMC and benefit from:}

- fast, convenient online submission

- thorough peer review by experienced researchers in your field

- rapid publication on acceptance

- support for research data, including large and complex data types

- gold Open Access which fosters wider collaboration and increased citations

- maximum visibility for your research: over $100 \mathrm{M}$ website views per year

At BMC, research is always in progress.

Learn more biomedcentral.com/submissions 